\title{
Enhanced rock-slope failure following ice-sheet deglaciation: timing and causes
}

\begin{tabular}{|r|l|}
\hline Journal: & Earth Surface Processes and Landforms \\
\hline Manuscript ID: & ESP-13-0185.R2 \\
\hline Date Submitted by the Author: & n/a \\
\hline Complete List of Authors: & $\begin{array}{l}\text { Ballantyne, Colin; University of St Andrews, School of Geography and } \\
\text { Geosciences } \\
\text { Wilson, Peter; University of Ulster, School of Environmental Sciences } \\
\text { Gheorghiu, Delia; SUERC, NERC Cosmogenic Isotope Analysis Facility } \\
\text { Rodés, Ängel; SUERC, NERC Cosmogenic Isotope Analysis Facility }\end{array}$ \\
\hline Keywords: & $\begin{array}{l}\text { paraglacial, rock-slope failure, surface exposure dating, stress release, } \\
\text { palaeoseismicity }\end{array}$ \\
\hline &
\end{tabular}

SCHOLARONE

Manuscripts 


\title{
Enhanced rock-slope failure following ice-sheet deglaciation: timing and causes
}

\author{
Colin K. Ballantyne ${ }^{1 *}$, Peter Wilson ${ }^{2}$, Delia Gheorghiu ${ }^{3}$ and Àngel Rodés ${ }^{3}$ \\ ${ }^{1}$ School of Geography and Geosciences, University of St Andrews, Scotland, UK. \\ 2 School of Environmental Sciences, University of Ulster, Coleraine, UK. \\ ${ }^{3}$ NERC Cosmogenic Isotope Analysis Facility, SUERC, East Kilbride, G75 0QF, UK \\ - Correspondence to Colin K. Ballantyne, School of Geography and Geosciences, University \\ of St Andrews, Fife KY16 9AL, Scotland, UK. Email: ckb@st-andrews.ac.uk
}

ABSTRACT: The temporal pattern of rock-slope failures (RSFs) following Late Pleistocene deglaciation on tectonically stable terrains is controversial: previous studies variously suggest (1) rapid response due to removal of supporting ice ('debuttressing'), (2) a progressive decline in RSF frequency, (3) a millennial-scale delay before peak RSF activity. We test these competing models through ${ }^{10} \mathrm{Be}$ exposure dating of five closely-spaced quartzite RSFs on the Isle of Jura, Scotland, to establish the relationship between timing of failure and those of deglaciation, episodes of rapid warming and periods of rapid glacio-isostatic uplift. All five dated RSFs occurred at least 720-2240 years after deglaciation, with the probability of failure peaking $\sim 2$ ka after deglaciation, consistent with millennial-scale delay model (3). This excludes debuttressing as an immediate cause of failure, though it is likely that timedependent stress release due to deglacial unloading resulted in progressive development of failure planes within the rock. Thaw of permafrost ice in joints is unlikely to have been a prime trigger of failure as some RSFs occurred several centuries after the onset of interstadial warming. Conversely, the timespan of the RSFs coincides with the period of maximum glacio-isostatic crustal uplift, suggesting that failure was triggered by uplift-driven seismic events acting on fractured rock masses. Implications of this and related research are: (1) that retreat of the last Pleistocene ice sheets across tectonically-stable mountainous terrains was succeeded by a period of enhanced rock-slope failure due to deglacial unloading and probably uplift-driven seismicity; (2) that the great majority of RSFs in the British Isles outside the limits of Loch Lomond Stadial (= Younger Dryas) glaciation are of Lateglacial (preHolocene) age; and (3) numerous RSFs must also have occurred inside Loch Lomond Stadial glacial limits, but that runout debris was removed by LLS glaciers.

Keywords: Rock-slope failure; paraglacial; surface exposure dating; stress release; palaeoseismicity. 


\section{Introduction}

Many formerly-glaciated mountains are characterized by numerous large-scale postglacial rock-slope failures (RSFs) in the form of major rockfalls, topples, rockslides, rock avalanches or deep-seated gravitational slope deformations. Such RSFs are often described as paraglacial, implying that failure has been conditioned by the preceding episode of glaciation and deglaciation, though the role of deglacial stress release and its interaction with other factors (such as progressive failure, thaw of ice in rock joints and seismic activity) remains incompletely understood (Ballantyne, 2002; Leith et al., 2011; McColl, 2012). A particularly interesting question concerns the response time of major postglacial RSFs following deglaciation, and its implications for the factors responsible for triggering failure: do potentially unstable rockwalls respond rapidly to ice-sheet thinning and associated changes in stress, or are failure events distributed throughout postglacial time?

Surface exposure dating using cosmogenic isotopes (principally ${ }^{10} \mathrm{Be}$ and ${ }^{36} \mathrm{Cl}$ ) is now routinely employed to establish the age of postglacial RSFs, particularly in tectonicallyactive mountain belts (Ivy-Ochs and Schaller, 2010). Exposure dating of RSFs has been employed, for example, to investigate the evolution of slope deformations (BigotCormier et al., 2005; Agliardi et al., 2009; El Bedoui et al., 2009; Hippolyte et al., 2009), to constrain the extent of Pleistocene glacier advances (Sanhueza-Pino et al., 2011), to determine the level of hazard at former landslide sites (Welkner et al., 2010), to estimate long-term rates of pre-failure sliding (Hermanns et al., 2012) and to determine the contribution of RSFs to postglacial denudation and landscape evolution (Barnard et al., 2001; Antinao and Gosse, 2009; Seong et al., 2009; Hewitt et al., 2011; Shroder et al., 2011). The timing of individual dated RSFs has been variously related to deglacial unloading and stress release (Cossart et al., 2008; Shroder et al., 
2011), seismic triggering or neotectonic activity (Mitchell et al., 2007; Antinao and Gosse, 2009; Sanchez et al., 2010; Stock and Uhrhammer, 2010; Hermanns and Niedermann, 2011; Hewitt et al, 2011; Penna et al., 2011) or climatic controls (Hermanns and Schellenberger, 2008; Hormes et al., 2008; Dortch et al., 2009; IvyOchs et al., 2009).

Few of the above studies, however, specifically address the question of the temporal pattern of RSFs following Late Pleistocene deglaciation and the implications of this pattern for failure mechanisms. Cruden and $\mathrm{Hu}$ (1993) proposed that the frequency of failure declines exponentially with time elapsed since deglaciation, and several authors have suggested that the frequency of large RSFs peaks immediately after deglaciation and declines thereafter (Abele, 1974; Soldati et al., 2004). Documented cases of rock-slope failure following recent glacier retreat (e.g. Evans and Clague, 1994; Ballantyne, 2002; Arsenault and Meigs, 2005; Allen et al. 2010) provide some support for this idea. Equally, however, many of the references cited above provide evidence of large-scale RSFs that occurred several millennia after Late Pleistocene deglaciation (see also Hewitt et al., 2008, and references therein). A global dataset of 32 dated postglacial RSFs compiled by McColl (2012) showed clustering in the early Holocene (10-8 ka), but as these occurred in areas of variable relief, tectonic activity and deglacial chronology, it is difficult to draw meaningful conclusions.

Support for the idea of fairly rapid (Lateglacial and early Holocene) RSF response to Late Pleistocene deglaciation is provided by Fauqué et al. (2009), who dated very large postglacial rock avalanches in the southern Andes. Apart from one anomalously old age, their 11 dates all fall within the period from $\sim 13.9 \mathrm{ka}$ to $\sim 8.2 \mathrm{ka}$, with no evidence for later activity. Similarly, using stratigraphic estimation of the approximate 
ages of rock avalanches terminating in fjords in western Norway, Longva et al. (2009) concluded that $89 \%$ of the total volume of rock avalanche runout occurred during deglaciation $(\sim 14.7 \mathrm{ka}$ to $\sim 11.7 \mathrm{ka})$, though RSF frequency apparently peaked in the early Holocene $(\sim 11.7 \mathrm{ka}$ to $\sim 10.0 \mathrm{ka})$. Some researchers have championed the view that a period of greatly enhanced RSF activity occurred over several millennia following ice-sheet deglaciation as a consequence of large-magnitude seismic events due to fault movements driven by rapid glacio-isostatic crustal uplift (e.g. Mörner, 1991, 2004; Lagerbäck, 1992; Mercier et al., 2013; Cossart et al., 2013), but hitherto the dating evidence required to substantiate this interpretation has been inadequate.

In the Scottish Highlands, Ballantyne and Stone (2013) obtained 47 surface exposure ages $\left({ }^{10} \mathrm{Be}\right.$ and $\left.{ }^{36} \mathrm{Cl}\right)$ for the runout zones of 17 catastrophic RSFs. These yielded ages from $\sim 17.0 \mathrm{ka}$ to $\sim 1.5 \mathrm{ka}$; ten sites produced Lateglacial and early Holocene (>9.8 ka) ages, and the ages for the remaining seven sites are scattered throughout the Holocene without significant clustering. By comparing each age with the approximate timing of deglaciation at each site, they showed that the dated Scottish RSFs fall into two groups: 'rapid response' RSFs that failed during or within a millennium after deglaciation (seven sites) and delayed response RSFs that failed at various times throughout the Lateglacial and Holocene. The dataset they used, however, suffers from three weaknesses: (1) it includes both sites deglaciated prior to 14.5 $\mathrm{ka}$ as the last British-Irish Ice Sheet retreated, and sites deglaciated much later following limited reoccupation of Highland valleys by glacier ice during the Loch Lomond (= Younger Dryas) Stade (LLS) of $\sim 12.9-11.7 \mathrm{ka}$; (2) the deglaciation ages of some sites are not accurately determined, making assessment of time elapsed since deglaciation imprecise; and (3) the dated RSFs occur on a wide range of lithologies, so possible structural controls are ignored. The aim of the research reported here is to 
establish both the deglaciation age and timing of RSFs for a closely-spaced cluster of RSFs on the Paps of Jura in the Inner Hebrides off the west coast of Scotland, and to determine the temporal pattern of RSF occurrence and its implications in terms of possible causes. This area was chosen because all RSF sites are seated on a uniform lithology, there is no evidence for reoccupation of RSF sites by glacier ice following ice-sheet deglaciation, and the RSFs are so closely spaced that we can assume quasi-synchronous deglaciation, constrained by exposure ages obtained on a nearby moraine.

\section{The Paps of Jura}

The Paps of Jura $\left(55^{\circ} 52^{\prime}-55^{\circ} 54^{\prime} \mathrm{N}, 05^{\circ} 57^{\prime}-06^{\circ} 01^{\prime} \mathrm{W}\right.$; Figure 1) comprise three mountains, Beinn a'Chaolais $(733 \mathrm{~m})$, Beinn an Oir $(785 \mathrm{~m})$ and Beinn Shiantaidh (757 m). All are underlain by massive fine- to medium-grained Dalradian quartzites that dip ESE at $25-40^{\circ}$ and are locally intruded by doleritic dykes (Walker, 1961; Anderton, 1976, 1977, 1985).

When the last British-Irish Ice Sheet reached its maximum extent at $\sim 27-26 \mathrm{ka}$, westwards-moving ice crossed Jura and extended to the Atlantic shelf edge, $195 \mathrm{~km}$ west of the island (Hubbard et al., 2009; Clark et al., 2012). The westward reach of the last ice sheet implies that it must have buried all mountain summits on Jura (cf. Fabel et al., 2012). This is confirmed by observations of ice-moulded bedrock at up to $660 \mathrm{~m}$ altitude on Beinn an Oir, and by the presence of rhyolitic erratics and glacially-rounded and facetted boulders on the summit $(785 \mathrm{~m})$ of the same mountain (Ballantyne, 1999), though slopes bordering the summit plateaux of all three mountains are mantled by steep bouldery scree deposits. The timing of ice-sheet deglaciation is poorly constrained, but a radiocarbon age obtained for a mollusc from an offshore 
core recovered $4 \mathrm{~km}$ south of Jura implies ice-sheet deglaciation of the area before $\sim 15$ cal ${ }^{14} \mathrm{C}$ ka (Peacock, 2008; Clark et al., 2012). There is no convincing evidence for reoccupation of Jura by glacier ice during the Loch Lomond Stade of $\sim 12.9-11.7$ $\mathrm{ka}$, implying that the Paps of Jura have escaped glaciation since the retreat of the last ice sheet from the area.

Jura occupies a tectonically-stable intraplate location characterised by low-magnitude $\left(M_{L}<4.0\right)$ seismic activity (Musson, 2007). No seismic events exceeding $M_{L} 3.5$ have been recorded on Jura or the adjacent shelf within the past $\sim 40$ years of instrumental observations (Julian Bukits, personal communication, March 2013).

\section{The Jura RSFs}

Ballantyne (1999) described evidence for rock-slope failure on all three mountains in the form of displaced rock masses and fissures on summit rims. Evidence for debris runout associated with catastrophic failure is limited to six sites, five of which were sampled for exposure dating and are described below. At all these sites the morphological evidence (Figure 2) appears consistent with a single major failure episode, though we cannot exclude the possibility at some sites of later emplacement of debris by rockfall, debris flow or minor secondary RSF events. All RSF runout deposits terminate abruptly at the slope foot (Figure 2), demonstrating that they have not been modified by glacier ice and must have occurred after retreat of the last ice sheet.

\section{Beinn Shiantaidh RSF}

The Beinn Shiantaidh (BS) RSF represents a major rockslide or rock avalanche from the eastern flank of Beinn Shiantaidh. The crown of the failure zone is represented by an indented line of cliffs at 600-700 m altitude just below the summit (Figure 2a), and 
the runout zone by a spectacular deposit of boulders that extends $380 \mathrm{~m}$ along the foot of the slope and $180 \mathrm{~m}$ outwards over the adjacent level ground. The most conspicuous feature of the runout zone is a massive arcuate distal ridge (Figure 2b) that terminates abruptly outwards and encloses a depression up to $6 \mathrm{~m}$ deep and an inner zone of large boulders. Dawson (1977) calculated that the deposit has a minimum volume of $185,000 \mathrm{~m}^{3}$, implying failure of at least $0.37 \mathrm{Mt}$ of rock. The BS RSF runout deposit was interpreted by Dawson (1977) as a relict rock glacier, but this interpretation appears unwarranted as its morphology is consistent with RSF runout without the need to invoke internal deformation of a former body of ice or ice-rich permafrost (Jarman et al., 2013). The distal ridge is interpreted as representing impact of avalanching debris on the level ground at the foot of the slope, which caused the debris to accumulate as a crescentic ridge around the impact zone. Similar instances of arcuate impact ridges developed at a basal break of slope have been documented in NW Scotland (Ballantyne and Stone, 2009) and at the foot of quartzite mountains in Donegal (Wilson, 2004).

\section{Beinn a'Chaolais RSFs}

The SE flank of Beinn a'Chaolais exhibits evidence for deep-seated gravitational slope deformation in the form of displaced rock masses, bulging slopes and rock benches. The Beinn a'Chaolais South (BCS) RSF apparently reflects collapse of the ridge crest and runout of bouldery debris at the foot of a gully near the southern margin of the displaced rock mass, forming a broad bouldery runout lobe with a gently-sloping distal rim (Figure 2c). The Beinn a'Chaolais East (BCE) RSF runout (Figure 2d) forms a massive debris lobe, at least $15 \mathrm{~m}$ thick at its distal end, near the northern margin of the zone of displaced rock. It appears to have been sourced from near the top of the slope where a low cliff marks the failure headscarp. The Beinn a'Chaolais West 
(BCW) failure scar is represented by a funnel-shaped re-entrant in a line of summit cliffs. Below a broad talus cone, coarse debris extends over 200 m over gently sloping ground in the form of two elongate lobes (Figure 2e) separated by a bedrock knoll. Dolerite boulders on the northern lobe appear to be derived from a dyke in the summit cliffs. Excess runout over low gradients suggests that these lobes may reflect emplacement by RSF-generated debris flows, though they lack the pronounced bouldery levées characteristic of rockslide-sourced debris flows on the Scottish mainland (Ballantyne, 1992, 2007).

\section{Beinn an Oir East RSF}

The eastern slope of Beinn an Oir also exhibits evidence for deep-seated deformation, particularly evident in the form of a ramp of displaced bedrock. The Beinn an Oir East (BOE) RSF is located at the southern end of this ramp, and comprises a shallow headscarp and boulder-covered slope with limited debris runout (Figure 2f).

\section{Sampling and sample preparation}

Rock samples for ${ }^{10} \mathrm{Be}$ surface exposure dating were chiseled from near-horizontal top surfaces of three large boulders on each of the five RSF runout zones (Figure 3). All sampled boulder surfaces comprised apparently unweathered quartzite; weathering rinds were absent in all cases, and boulders that could have toppled from their original positions were avoided. Where possible, samples were obtained from boulders on the distal part of runout zones (Figure 1) to reduce the possibility of sampling boulders deposited by later rockfall events.

To establish the timing of deglaciation in the area, four additional samples were obtained from quartzite boulders on the Sgriob na Caillich moraine, which stretches 3.5 km WNW from the foot of Beinn an Oir and is composed of parallel belts of 
angular quartzite boulders, but lacks surface relief (Figures 1 and 4). Because the moraine terminates at the Lateglacial marine limit, Dawson (1979) argued that this feature is a medial moraine deposited during retreat and thinning of the last ice sheet, rather than a lateral moraine marking the extent of a later glacial readvance. The large volume of debris in the moraine and the angularity of the boulders suggests that the moraine represents supraglacial transport of RSF debris dumped on the thinning ice surface by failure of the rock slope SW of the summit of Beinn an Oir (now represented by deeply-indented twin failure scars; Figure 1 and Figure 4a) then deposited shortly afterwards as the ice downwasted. This interpretation implies that the higher parts of the Paps of Jura above $\sim 550 \mathrm{~m}$ had already emerged from the ice surface as nunataks before the moraine was deposited, so that the age of the moraine provides a reasonable approximation for complete deglaciation of the area. Samples for exposure dating were taken from boulders protruding from the moraine surface to minimise the possibility of former sediment or peat cover.

At all sites a skyline survey was carried out to allow calculation of the effects of topographic shielding. Multiple caliper measurements were made on each sample to determine sample thickness, then samples were crushed and sieved. All samples were prepared at the NERC Cosmogenic Isotope Analysis Facility at SUERC, East Kilbride. Quartz was separated from the 250-500 $\mu \mathrm{m}$ fraction using magnetic separation and hexafluorosilicic acid etching. The isolated quartz was cleaned in $16 \%$ hydrofluoric acid on a shaker table to remove remaining contaminants and meteoric ${ }^{10} \mathrm{Be}$ by etching $>30 \%$ of each sample, following procedures modified from Kohl and Nishiizumi (1992). BeO targets were prepared for ${ }^{10} \mathrm{Be} /{ }^{9} \mathrm{Be}$ analysis using procedures modified from Child et al. (2000), and ${ }^{10} \mathrm{Be} /{ }^{9} \mathrm{Be}$ ratios were measured with the $5 \mathrm{MV}$ Pelletron AMS at SUERC (Xu et al., 2010). ${ }^{10} \mathrm{Be} /{ }^{9} \mathrm{Be}$ ratios were normalized to NIST 
SRM 4325 with a ${ }^{10} \mathrm{Be} /{ }^{9} \mathrm{Be}$ ratio of $2.79 \times 10^{-11}$ (in agreement with Nishiizumi et al., 2007). Secondary standard measurements scattered with less than $3 \%$ standard deviations. The processed blank ${ }^{10} \mathrm{Be} /{ }^{9} \mathrm{Be}$ ratios were between 1 and $6 \%$ of the sample ${ }^{10} \mathrm{Be} /{ }^{9} \mathrm{Be}$ ratios and were subtracted from the measured ratios. The uncertainty of this correction is included in the stated standard uncertainties. Details of sample locations and relevant analytical data are given in Table 1.

\section{Exposure age calibration and scaling}

Exposure ages were calculated using the CRONUS-Earth online calculator (Developmental version; wrapper script 2.2, main calculator 2.1, constants 2.2.1, muons 1.1; Balco et al., 2008) and calibrated using two locally-derived ${ }^{10} \mathrm{Be}$ production rates (LPRs) to minimise scaling uncertainty (e.g. Balco et al., 2009; Kaplan et al., 2010; Balco, 2011). The first, the Loch Lomond local production rate (LL LPR) is based on ${ }^{10} \mathrm{Be}$ concentration in samples from boulders on the terminal moraine of the glacier that advanced to the southern end of Loch Lomond, $\sim 95 \mathrm{~km}$ ENE of the Paps of Jura, during the Loch Lomond Stade (Fabel et al., 2012; D. Fabel, personal communication, November 2012). The age of this moraine is independently constrained by radiocarbon dating (MacLeod et al., 2011), and the measured ${ }^{10} \mathrm{Be}$ concentrations imply a reference ${ }^{10} \mathrm{Be}$ production rate ( $\mathrm{Lm}$ scaling) of $3.92 \pm 0.18$ atoms $\mathrm{g}^{-1} \mathrm{a}^{-1}$.

The second LPR we employ is the NWH11.6 LPR. The calibration data can be accessed at http://depts.washington.edu/cosmolab/cronus/cronus cal.html, and further site and analytical details are given in Ballantyne and Stone (2012). This LPR is based on samples from glacially-deposited boulders and bedrock surfaces inside the limits of small glaciers that formed in NW Scotland (160-180 km north of the Paps 
of Jura) during the Loch Lomond Stade. This LPR is based on an assigned deglacial exposure age of $11.6 \pm 0.3 \mathrm{ka}$, yielding a reference ${ }^{10} \mathrm{Be}$ production rate ( $\mathrm{Lm}$ scaling) of $4.20 \pm 0.14$ atoms $\mathrm{g}^{-1} \mathrm{a}^{-1}$ for an assumed surface erosion rate of $1 \mathrm{~mm} \mathrm{ka}^{-1}$. These two LPRs were selected as they bracket the range of possible exposure ages for our samples (cf. Fabel et al., 2012). Use of the NWH11.6 LPR produces exposure ages 6.85-7.00\% younger than use of the LL LPR, or roughly 1000 years younger for LL LPR ages of 14-15 ka. To avoid citation of paired ages, we base the discussion below on the ages derived using LL LPR, with the caveat that true exposure ages may be up to $7 \%$ younger. Where citation of both ages is necessary, the age derived using LL LPR is cited first, followed in brackets by the age derived using NWH11.6 LPR.

An additional advantage of using LPRs is that the variability amongst different production rate scaling schemes (the St, Lm, Li, De and Du schemes of the CRONUSEarth calculator) is reduced. Here we report ages using the time-dependent Lm scheme (Lal, 1991; Stone 2000), which is widely used in studies of deglaciation chronology in the British Isles. Lm scaling produces the youngest ages for our samples; other scaling schemes produce ages up to $1.5 \%$ older. We assume a surface erosion rate $(\varepsilon)$ of $1 \mathrm{~mm} \mathrm{ka}^{-1}$, which is reasonable for crystalline rocks (Ballantyne, 2010); $\varepsilon=0$ reduces our reported ages by $\sim 1 \%$, and $\varepsilon=2 \mathrm{~mm} \mathrm{ka}^{-1}$ increases the reported ages by a similar margin. Assumption of a particular LPR, scaling scheme or erosion rate has negligible effect on the temporal pattern of RSFs relative to deglaciation age, as all ages are affected proportionally. Uncertainties cited below are external (total) uncertainties at $\pm 1 \sigma$. 
305

306

\section{Results}

Table 2 and Figure 5 summarise the exposure dating results for both LPRs. Tests of difference between ages were based on the two-sample difference of means test.

\section{Deglaciation ages}

Samples SNC-06 and SNC-07 from the Sgriob na Caillich medial moraine yielded almost identical ages $(16.88 \pm 1.10 \mathrm{ka}$ and $16.82 \pm 1.03 \mathrm{ka}$ respectively, with a weighted mean age of $16.84 \pm 0.93 \mathrm{ka}$ ). Both samples were obtained at a point where the moraine crosses a bedrock knoll. Sample SNC-02 (14.01 $\pm 1.69 \mathrm{ka})$ and sample SNC-03 (12.35 $\pm 1.41 \mathrm{ka})$ both differ significantly from this weighted mean age (at $p<0.1$ and $p<0.05$ respectively), and we interpret these ages as reflecting former burial of the boulders from which they were obtained under sediment and/or peat cover (Putkonen and Swanson, 2003; Heyman et al., 2011), consistent with the absence of relief on the medial moraine (Figure 4). Both of these ages, moreover, post-date the oldest RSFs in the Paps of Jura (the Beinn Shiantaidh and Beinn a'Chaolais West RSFs; Table 2), and as the RSF runout deposits show no sign of glacial modification it is reasonable to infer complete deglaciation of Jura before the oldest RSFs occurred. The ages obtained for SNC-02 and SNC-03 also postdate rapid warming at the onset of the Lateglacial Interstade at $\sim 14.7 \mathrm{ka}$ (Brooks and Birks, 2000; Brooks et al., 2012), by which time the ice-sheet margin had retreated inland from the western seaboard of mainland Scotland (Hubbard et al., 2009; Ballantyne and Stone, 2012; Clark et al., 2012), implying prior deglaciation of most or all of the Inner Hebrides. We therefore exclude both these ages and assume that the weighted mean age of $16.84 \pm 0.93 \mathrm{ka}(15.75 \pm 0.53 \mathrm{ka})$ for samples SNC-06 and SNC-07 approximates the timing of the deglaciation of west-central Jura. This conclusion is consistent with the minimum deglaciation age of $\sim 15$ cal ${ }^{14} \mathrm{C}$ ka obtained for a mollusc 
recovered from an offshore core recovered $4 \mathrm{~km}$ south of Jura (Peacock, 2008). If sample SNC-02 (14.01 $\pm 1.69 \mathrm{ka})$ is included, the weighted mean age for deglaciation differs only slightly $(16.61 \pm 0.88 \mathrm{ka})$, and does not significantly affect analysis of RSF ages in terms of time elapsed since deglaciation.

\section{RSF ages}

${ }^{10} \mathrm{Be}$ exposure ages for individual RSF samples (LL LPR) range from $20.57 \pm 1.56 \mathrm{ka}$ to $8.54 \pm 0.52 \mathrm{ka}$ (Figure 5 and Table 2). However, samples BS-03 (19.22 $\pm 1.14 \mathrm{ka}$ ) and BOE-03 $(20.57 \pm 1.56 \mathrm{ka})$ produced ages significantly older $(p<0.01)$ than the weighted mean deglaciation age implied by the Sgriob na Caillich moraine samples. Both ages are also significantly older $(p<0.001)$ than the others obtained from the same RSF runout deposit. We attribute these two anomalies to sampling boulders derived from at or near the former cliff face prior to failure, and thus exposed to cosmic radiation before failure occurred, a common occurrence in some RSF runout deposits as boulders derived from near the pre-failure rock face may be rafted on the surface of the mobile debris (Ivy-Ochs et al., 2009; Ivy-Ochs and Schaller, 2010). These two ages are therefore excluded from further analysis. We also exclude sample BCE-02 $(9.56 \pm 0.57 \mathrm{ka})$, which is significantly younger $(p<0.001)$ the two other ages (13.92 $\pm 0.84 \mathrm{ka}$ and $13.44 \pm 0.81 \mathrm{ka}$ ) obtained from the same site, and probably reflects later rockfall deposition after the main failure at this site.

After exclusion of these three ages, three of the RSF runout deposits (BS, BCS and BCE) yielded pairs or triplets of statistically indistinguishable exposure ages with reduced chi-square values $<1.0$, consistent with sampling from a single age population (Balco, 2011). For these three runout deposits we calculated uncertaintyweighted mean ages of $15.11 \pm 0.81 \mathrm{ka}, 14.81 \pm 0.56 \mathrm{ka}$ and $13.67 \pm 0.73 \mathrm{ka}$ respectively for the timing of rock-slope failure (Table 2). The remaining two runout 
sites yielded exposure ages that differ from all others from the same site at $p<0.05$.

In these cases we infer that the main failure event is represented by the oldest postdeglaciation age from these sites, represented by sample BCW-04 (15.37 $\pm 0.92 \mathrm{ka})$ and sample BOE-05 (14.38 $\pm 0.88 \mathrm{ka})$, with younger ages reflecting boulder deposition by later debris-flow events (at BCW) or rockfall (at $\mathrm{BOE}$ ). It is also possible that the younger ages from these two sites represent shielding by former sediment cover (Putkonen and Swanson, 2003; Heyman et al., 2011), though we encountered no evidence for sediment or peat cover on any of the bouldery RSF deposits (Figure 3). Interpretation of the exposure ages for samples BCW-04 and BOE-05 as representative for these RSFs implies that failure at all five dated Jura RSF sites occurred between $15.37 \pm 0.92 \mathrm{ka} \quad(14.37 \pm 0.74 \mathrm{ka}) \quad$ and $\quad 13.67 \pm 0.73 \mathrm{ka}$ $(12.78 \pm 0.57 \mathrm{ka})$. However, it is possible that one or more of the younger ages obtained for BCW and BOE identify the timing of initial failure and that the ages obtained for BCW-04 and BOE-05 represent nuclide inheritance, though this appears unlikely as it implies a complex exposure history for these samples that has fortuitously produced ages similar to those of the other three dated RSFs. Thus although the BCW samples are interpreted below as representing rock-slope failure at $15.37 \pm 0.92 \mathrm{ka}$, we cannot exclude the possibility of later or possibly renewed failure, as represented by samples BCW-01 (12.06 $\pm 0.72 \mathrm{ka})$ or BCW-03 (10.08 $\pm 0.61 \mathrm{ka})$. Similarly, although the two post-deglaciation ages obtained for the BOE RSF are interpreted as indicating failure at $14.38 \pm 0.88 \mathrm{ka}$, we cannot exclude the possibility of later failure at $8.54 \pm 0.52 \mathrm{ka}$ (sample BOE-04).

In summary, the weighted mean ages obtained for three RSFs (BS, BCS and BCE) and the oldest postglacial ages obtained for the remaining two RSFs (BCW, BOE) all fall within the period of the Late Devensian (Late Weichselian) Lateglacial between 
385

386

387

388

389

390

391

392

393

394

395

396

397

398

399

400

401

402

403

404

405

406

407

408

409

410

$15.37 \pm 0.92 \mathrm{ka}(14.37 \pm 0.75 \mathrm{ka})$ to $13.67 \pm 0.73 \mathrm{ka}(12.78 \pm 0.57 \mathrm{ka})$, and thus imply that at least three of the RSFs (and probably all five) occurred in the interval between ice-sheet deglaciation at $\sim 16.8 \mathrm{ka}(\sim 15.8 \mathrm{ka})$ and the beginning of the LLS at $\sim 12.9$ ka. However, if the younger ages obtained for BCW and BOE are representative for these sites, these imply that failure (or renewed failure) at BCW may have occurred as late as $10.08 \pm 0.61 \mathrm{ka}(9.43 \pm 0.50 \mathrm{ka})$ and that at $\mathrm{BOE}$ as late as $8.54 \pm 0.52 \mathrm{ka}$ $(7.99 \pm 0.42 \mathrm{ka})$.

\section{RSF timing and causes of failure}

An extensive body of literature suggests a temporal and causal association between deglaciation of steep rockwalls and subsequent catastrophic rock-slope failure, both with regard to recent glacier shrinkage (Evans and Clague, 1994; Ballantyne, 2002; Arsenault and Meigs, 2005) and Late Pleistocene or early Holocene deglaciation (e.g. Soldati et al., 2004; Blikra et al., 2006; Fauqué et al., 2009; Longva et al., 2009; Mercier et al., 2013). Explanations for this association fall into three main classes: (1) processes associated with deglaciation or deglacial unloading at the local scale ('debuttressing' and paraglacial stress release); (2) warming and thaw of permafrost ice in joints; and (3) processes associated with deglacial unloading at a regional scale (glacio-isostatic crustal uplift and associated seismicity). Two or more of these may operate in conjunction to reduce rock-mass strength to a state of critical conditional stability and ultimately to trigger failure. Examination of the timing of the individual RSFs on Jura in relation to deglaciation (Figure 6) and regional environmental changes (Figure 7) nevertheless allows some assessment of causes of failure. 
Deglaciation, 'debuttressing' and stress release

The exposure ages reported above (Table 2) imply that all five dated RSFs on Jura occurred at least 770-2240 years after deglaciation (figure 6). The oldest RSF (BCW) is significantly younger than the inferred timing of deglaciation at $p<0.1$, and all other RSF ages are significantly younger at $p<0.01$ or $p<0.001$. If removal of supporting glacier ice during deglaciation ('debuttressing') was the cause of failure, then RSF ages should be indistinguishable from deglaciation age. The millennial-scale delay in RSF activity following deglaciation (Figure 6) indicates with $95 \%$ confidence that this was not so, and that 'debuttressing' can be excluded as a triggering mechanism in the case of the exposure-dated Jura RSFs. However, as outlined above, the Sgriob na Caillich moraine appears to represent the glacially-transported runout debris from rock-slope failure SW of the summit of Beinn an Oir. If this interpretation is correct, it implies that this failure occurred during ice-sheet thinning, possibly as a direct response to glacial debuttressing as the adjacent glacier ice surface thinned to $\sim 550-600 \mathrm{~m}$ altitude, exposing the adjacent rock slope.

Paraglacial (glacially-conditioned) stress release has been widely invoked as a factor in explaining RSFs in formerly glaciated mountains, but the process is incompletely understood. Some authors have emphasised differential loading by glacier ice and subsequent unloading during deglaciation in altering the state of stress within rockwalls, others the effects of glacial erosion in changing the rockwall stress field, and others still the role of glacier ice in suppressing in situ rock stresses resulting from the tectonic and erosional history of the rock mass, with consequent reduction in confining stress during deglaciation (e.g. Augustinus, 1995; Cossart et al., 2008; Amadei and Stephansson, 1997; Leith et al. 2010, 2011). Irrespective of the cause of paraglacial stress release, there is agreement that it is responsible for fracture 
437

438

439

440

441

442

443

444

445

446

447

448

449

450

451

452

453

454

455

456

propagation, and particularly for development of slope-parallel joints that form potential failure planes (Hencher et al., 2011; McColl, 2012). Although some authors have rejected stress release as the cause of postglacial rock-slope failure at sites where a millennial time lag separates deglaciation and failure (e.g. Mitchell et al., 2007; Prager et al., 2009; Hippolyte et al, 2009; Stock and Uhrhammer, 2010), it unquestionably plays a role in preconditioning slopes to failure, and probably accounts for the high incidence of RSFs in formerly-glaciated steeplands. This interpretation is supported by Cossart et al. (2008), who showed that postglacial RSFs in the western Alps occur where glacially-induced confining stresses were greatest. Moreover, geotechnical modelling by Eberhardt et al. (2004) and Gugliemi and Cappa (2010) indicates that the progressive loss of rock mass strength associated with paraglacial stress release may extend over several millennia, preconditioning rock masses to failure long after deglaciation, though failure itself may be precipitated by transient triggering factors such as seismic activity. The millennial-scale delay in rock-slope failure following deglaciation evident on Jura (Figure 6) is consistent with this view: fracture propagation and consequent progressive failure due to time-dependent release of strain energy in deglacially-unloaded rock masses might explain the temporal pattern of failure even in the absence of specific triggering mechanisms (Kemeny, 2003; Eberhardt et al., 2004; Brideau et al., 2009), though comparison with environmental changes at the time of the Jura RSFs (Figure 7) suggest that two triggering factors - thaw of ice in joints and seismotectonic activity - may have precipitated failure of fractured rock.

\section{Warming and thaw of ice in ice-bonded rock}

Warming and thaw of permafrost ice within jointed rock masses has been shown to reduce rock mass strength and trigger rock-slope failure (e.g. Davies et al., 2001; 
463

464

465

466

467

468

469

470

471

472

473

474

475

476

477

478

479

480

481

482

483

484

485

486

487

488

489

Gruber and Haeberli, 2007; Haeberli et al., 2008; Krautblatter et al., 2012, 2013).

Permafrost is known to have developed in northern Britain in the wake of ice-sheet retreat (Ballantyne and Harris, 1994). It is therefore possible that ice formed within rock joints during this interval, increasing rock-slope stability, and that subsequent thaw of ice-bonded joints induced failure of rock slopes previously weakened by stress release and fracture propagation. Permafrost thaw was initiated by rapid warming at the onset of the Lateglacial Interstade $(\sim 14.7 \mathrm{ka})$, when mean July temperatures in Scotland increased by $6-7^{\circ} \mathrm{C}$ and mean January temperatures rose by up to $\sim 25^{\circ} \mathrm{C}$ over a few decades (Atkinson et al., 1987; Brooks and Birks, 2000; Brooks et al., 2012). If thaw of ice-bonded rock joints was responsible for triggering the Jura RSFs, it would be expected that the timing of RSFs would cluster within a few centuries following $14.7 \mathrm{ka}$. This is not the case. Irrespective of the LPR used in RSF age calculation, most best-estimate ages of the Jura RSFs either predate, or post-date by several centuries, this episode of rapid stadial-interstadial warming (Figure 7). The wide uncertainties associated with the RSF ages do not permit exclusion of thaw of ice-bonded rock as a trigger of kinematic release for individual RSFs, but this mechanism cannot apply in all cases.

\section{Glacio-isostatic rebound and palaeoseismicity}

There is growing evidence that earthquake activity on passive margins and intraplate areas was very much greater in the aftermath of Late Pleistocene deglaciation than at present (Gregerson and Basham, 1989; Stewart et al., 2000; Morner, 2005), reflecting both crustal uplift due to glacio-isostatic rebound and release of regional tectonic strain energy that had accumulated during the preceding period of ice-sheet glaciation (Muir-Wood, 2000). Large magnitude 'endglacial' earthquakes triggered by glacioisostatic uplift have been implicated as RSF triggers in Scotland, Fennoscandia and 
Iceland (Sissons and Cornish, 1982a, 1982b; Lagerbäck, 1992; Ballantyne, 1997; Mörner, 1991, 2004; Mörner et al., 2000; Mercier et al., 2013; Cossart et al., 2013), but in Scotland the evidence for a period of enhanced Lateglacial seismicity rests on uncertain foundations. Earlier accounts inferring large, tectonically-induced postglacial strike-slip faulting in western Scotland (Davenport et al., 1989; Ringrose, 1989a; Ringrose et al., 1991) have been questioned, and it appears that postglacial faulting may have been limited to the formation of metre-high scarps associated with differential crustal rebound (Firth and Stewart, 2000; Stewart et al., 2001). Smith et al. (2009) have suggested that markedly greater ( $>5 \mathrm{~m}$ ) Lateglacial vertical movement occurred along a listric fault on the Island of Raasay, (160 km N of the Paps of Jura) but the evidence for this may represent, at least in part, the effects of deep-seated gravitational slope deformation rather than neotectonic activity. Soft-sediment deformation structures of Lateglacial or early Holocene age at sites in western Scotland have been inferred to relate to $M \approx 4.6-6.4$ earthquakes, though some may have been triggered by catastrophic drainage of glacial lakes rather than crustal uplift (Davenport and Ringrose, 1987; Ringrose 1989a, 1989b; Fenton, 1992; Stewart et al., 2001). The available evidence appears compatible with enhanced Lateglacial and early Holocene seismicity in Scotland due to glacio-isostatic crustal rebound, but the magnitude of earthquake activity at this time remains uncertain (Firth and Stewart, 2000).

For a site at Arisaig in Western Scotland (110 km north of the Paps of Jura), Firth and Stewart (2000) derived rates of crustal uplift based on a sea-level curve produced by Shennan et al. (1995). Their data show that the maximum averaged rates of uplift (14.3-26.7 $\mathrm{mm} \mathrm{a}^{-1}$ ) occurred during the period $\sim 15.7-12.7 \mathrm{ka}$, then dropped to $\sim 12.9 \mathrm{~mm} \mathrm{a}^{-1}$ during $\sim 12.7-10.7 \mathrm{ka}$ and $\sim 4.2 \mathrm{~mm} \mathrm{a}^{-1}$ within the period $\sim 10.7-7.1 \mathrm{ka}$. 
The inferred Lateglacial timing of the Jura RSFs coincides with the period of most rapid crustal uplift (Figure 7), suggesting that the two may be linked through seismic triggering of failure by uplift-induced earthquake activity. Such low-resolution temporal coincidence is not proof of causation, but suggests that the role of uplift-driven seismicity in triggering paraglacial RSFs in Scotland, downplayed in some recent studies (Jarman, 2006; Ballantyne and Stone, 2013), requires re-evaluation.

\section{Comparisons and implications}

Our results accord closely with exposure ages obtained from 14 other RSF sites that were deglaciated during retreat of the last British-Irish Ice Sheet but escaped glacial reoccupance during the LLS of $\sim 12.9-11.7 \mathrm{ka}$. Nine exposure-dated RSF runout deposits at the foot of quartzite mountains in NW Ireland produced ages of $17.7 \pm 0.9$ ka to $12.5 \pm 0.7 \mathrm{ka}$ (LL LPR) or $16.3 \pm 0.7 \mathrm{ka}$ to $11.7 \pm 0.5 \mathrm{ka}$ (NWH11.6 LPR), implying that all RSFs in this area occurred in the interval between deglaciation and the beginning of the Holocene at $\sim 11.7 \mathrm{ka}$ (Ballantyne et al., 2013). Similarly, five RSF runout deposits on granite and sandstone mountains in the Scottish Highlands yielded ages ranging from $\sim 16.9$ ka to $\sim 12.8$ ka (Ballantyne and Stone, 2013). For areas that lay outside the limits of LLS glaciation only one dated RSF has produced an unequivocal Holocene age: a major rockslide of basalt lavas, probably seated on underlying shale, that occurred on the Isle of Skye at $\sim 6.1 \mathrm{ka}$ (Ballantyne et al., 1998). Excluding this single exception (and possibly the BCW and/or BOE RSFs on Jura), all 20 dated RSFs outside the limits of LLS glaciation in the British Isles appear to have occurred between ice-sheet deglaciation and the beginning of the Holocene. This implies that the great majority of undated RSFs in British and Irish mountains outside the limits of LLS (Younger Dryas) glaciation also occurred during the Lateglacial period, within a few millennia of ice-sheet deglaciation 
During the Lateglacial Interstade of $\sim 14.7-12.9$ ka (Figure 7 ), glacier ice completely disappeared from upland Britain or survived only in favoured locations such as cirques or high plateaux (Finlayson et al., 2011; Ballantyne and Stone 2012; Fabel et al., 2012). The ensuing LLS of $\sim 12.9-11.7$ ka was a period of full-stadial climate during which glacier ice expanded to form a major icefield in the Western Highlands (Golledge, 2010), with peripheral icefields and numerous smaller glaciers in the Hebrides, northern Scotland, the eastern Grampians, English Lake District, NW Wales and the mountains of Ireland. As almost all dated RSFs that occur outside the limit of LLS glaciation occurred prior to the onset of the LLS, an interesting implication is that numerous Lateglacial RSFs presumably also occurred within areas reoccupied by glacier ice during the LLS but have not been recorded because RSF runout debris was removed by glaciers. Some of this 'lost generation' of Lateglacial RSFs may be identified from the morphology of failure scars, particularly where these are located above the upper limits of LLS glacier ice. Diagnostic criteria for such sites include steep headscarps separated by a break of slope from a subjacent failure plane, flank scarps, and tension cracks or detached blocks near the headscarp (Ballantyne, 2013). Implications of these debris-free Lateglacial RSF scars are: (1) that RSF inventories based on RSF runout or displaced rock masses (e.g. Jarman, 2006) underestimate the number of RSFs since ice-sheet deglaciation; (2) that RSFs may have played a more important role in the evolution of valley-side slopes and cirque evolution in upland Britain than has hitherto been appreciated; and (3) that RSFs probably made a significant contribution to the sediment budget of Younger Dryas glaciers in the British Isles, locally manifest in the form of exceptionally large end moraines and suites of hummocky recessional moraines (Ballantyne, 2013). 
More generally, the results from this study and those of Ballantyne and Stone (2013) and Ballantyne et al. (2013) support the conclusions of previous work in Scandinavia (Blikra et al., 2006; Longva et al., 2009), Iceland (Mercier et al., 2013) and the Andes (Fauqué et al., 2009) indicating a period of enhanced Lateglacial and early Holocene RSF activity following ice-sheet retreat, even though it is clear that many dated postglacial RSFs (particularly in tectonically active mountain belts) occurred several millennia after Late Pleistocene or early Holocene deglaciation (Hewitt et al., 2008; McColl, 2012). It seems reasonable to conclude that in intraplate areas of relative (present-day) tectonic stability, such as Scotland and Fennoscandia, paraglacial stress release and consequent fracture propagation have played a key role in preconditioning Lateglacial or early Holocene failures and that seismotectonic activity related to glacio-isostatic uplift probably triggered kinematic release in many cases.

\section{Conclusions}

${ }^{10} \mathrm{Be}$ exposure ages obtained on the runout debris of five postglacial rock-slope failures seated on the quartzite mountains of Jura demonstrate that at least three and probably all five occurred during the Late Devensian Lateglacial period, between 15.4 $\pm 0.9 \mathrm{ka}$ and $12.8 \pm 0.6 \mathrm{ka}$, though we cannot exclude a possible later age $(\sim 12-8 \mathrm{ka})$ for two of these. Comparison with a deglaciation age based on ${ }^{10} \mathrm{Be}$ exposure dating of a nearby medial moraine shows that all five dated RSFs occurred at least $770-2240$ years after deglaciation, implying that removal of ice during deglaciation (debuttressing) played no role in directly triggering failure at these sites. The RSF that apparently sourced the debris in the medial moraine, however, must have occurred as the last ice sheet downwasted below the level of the summits, and may represent a direct response to the removal of the support of adjacent glacier ice. Thaw of permafrost ice in ice-bonded rock joints seems unlikely to be implicated in failure of 
597

the dated RSFs, all of which pre-date or post-date (by several centuries) the rapid warming that occurred during the stadial-interstadial transition at $\sim 14.7 \mathrm{ka}$.

Paraglacial stress release due to deglacial unloading and/or reduction of confining stress is inferred to have contributed to rock-mass weakening through fracture propagation, and it is possible that all the dated RSFs reflect time-dependent release of strain energy, manifest through progressive development of failure planes, without recourse to a specific triggering mechanism. However, the timing of the dated RSFs on Jura coincides with the period of maximum glacio-isostatic crustal uplift on the west coast of the Scottish mainland, suggesting that the two may be linked through triggering of the Jura RSFs by uplift-driven seismic events acting on rock slopes weakened by stress release and associated fracture propagation.

Our results have several wider implications. The inferred Lateglacial timing of all dated RSFs on Jura contributes to growing evidence for a period of greatly enhanced RSF activity within a few millennia following ice-sheet retreat on intraplate terrains of relative (present-day) tectonic stability (e.g. Blikra et al., 2006; Longva et al., 2009; Ballantyne and Stone, 2013; Ballantyne et al., 2013). In particular, the timing of the Jura RSFs is consistent with the proposition that such enhanced Lateglacial RSF activity reflects triggering of failure by earthquakes associated with fault movements driven by rapid glacio-isostatic uplift over a period of a few millennia following icesheet retreat (e.g. Lagerbäck, 1992; Mörner, 1991, 2004; Mörner et al., 2000; Mercier et al., 2013; Cossart et al., 2013). Exposure dating of postglacial fault scarps (cf. Sanchez et al., (2010) may help confirm the temporal connections between uplift, palaeoseismicity and enhanced RSF activity following ice-sheet deglaciation 
More locally, comparison of the results reported here with those other studies devoted to dating of RSFs in the British Isles (Ballantyne and Stone, 2013; Ballantyne et al., 2013) shows that almost all dated RSFs located outside the limits of LLS glaciers occurred before the beginning of the Holocene at $\sim 11.7 \mathrm{ka}$, implying that the great majority of undated RSFs in such areas are also of Lateglacial age, and suggesting that the risk of future major RSFs in such areas is extremely low. Enhanced Lateglacial RSF activity outside the LLS glacial limits also implies that numerous RSFs must also have occurred inside these limits during the interval between ice-sheet retreat and the end of the LLS at $\sim 11.7 \mathrm{ka}$, but as the runout debris from such RSFs has been removed by LLS glaciers, are represented only by failure scars (Ballantyne, 2013). Identification of such 'empty' RSF source areas and assessment of their implications for long-term development of mountain form and the sediment budget of LLS glaciers represent interesting topics for further research.

\section{Acknowledgements}

This research was supported by the NERC Cosmogenic Isotope Analysis Facility through award of sample preparation and analysis (CIAF project 9046.0308) and by a grant from the British Society for Geomorphology in support of the cost of fieldwork on Jura. We thank Dr Derek Fabel of the University of Glasgow and Dr John Stone of the University of Washington for permission to use ${ }^{10} \mathrm{Be}$ calibration datasets in advance of publication. We also thank Sheng Xu and Dylan Rood (SUERC) for carrying out the AMS measurements and Graeme Sandeman (University of St Andrews) for drafting the figures. 
650

651

652

653

654

655

656

657

\section{References}

Abele G. 1974. Bergstürze in den Alpen: Ihre Verbreitung, Morphologie und Folgeerscheinungen. Deutscher und Österreichischer Alpenverein, Munich.

Agliardi F, Crosta GB, Zanchi A, Ravazzi C. 2009. Onset and timing of deep-seated gravitational slope deformations in the eastern Alps, Italy. Geomorphology 103: 113-129. DOI: 10.1016/j.geomorph.2007.09.015.

Allen S, Cox S, Owens I. 2010. Rock avalanches and other landslides in the central Southern Alps of New Zealand: a regional study considering possible climate change impacts. Landslides 8: 33-48. DOI: 10.1007/s10346-010-0222-z.

Amadei B, Stephansson O. 1997. Rock Stress and its Measurement. Chapman and Hall, London.

Antinao JL, Gosse J. 2009. Large rockslides in the southern central Andes of Chile (32-34.5 ${ }^{\circ} \mathrm{S}$ : tectonic control and significance for Quaternary landscape evolution. Geomorphology 104: 117-133. DOI: 10.1016/j.geomorph.2008.08.008.

Anderton R. 1976. Tidal shelf sedimentation: an example from the Scottish Dalradian. Sedimentology 23: 42-458.

Anderton R. 1977. The Dalradian rocks of Jura. Scottish Journal of Geology 13: 135142.

Anderton R. 1985. Sedimentation and tectonics in the Scottish Dalradian. Scottish Journal of Geology 21: 407-436.

Arsenault AM, Meigs AJ. 2005. Contribution of deep-seated bedrock landslides to erosion of a glaciated basin in southern Alaska. Earth Surface Processes and Landforms 30: 1111-1125. DOI: 10.1002/esp1265.

Atkinson TC, Briffa KR, Coope GR. 1987. Seasonal temperatures in Britain during the past 22,000 years, reconstructed using beetle remains. Nature 325: 587-592.

Augustinus PC. 1995. Glacial valley cross-profile development: the influence of in situ rock stress and rock mass strength, with examples from the Southern Alps, New Zealand. Geomorphology 14: 87-97.

Balco G. 2011. Contributions and unrealized potential contributions of cosmogenicnuclide exposure dating to glacier chronology, 1990-2010. Quaternary Science 
Reviews 30: 3-27. DOI: 10.1016/j.quascirev.2010.11.003

Balco G, Briner J, Finkel RC, Rayburn JA, Ridge JC, Schaefer JM. 2009. Regional beryllium-10 production rate calibration for late-glacial northeastern North America. Quaternary Geochronology 4: 93-107. DOI: 10.1016/j.quageo.2008.09.001

Balco G, Stone JO, Lifton NA, Dunai TJ. 2008. A complete and easily accessible means of calculating surface exposure ages or erosion rates from $10 \mathrm{Be}$ and $26 \mathrm{Al}$ measurements. Quaternary Geochronology 3: 174-195. DOI: 10.1016/j.quageo.2007.12.001.

Ballantyne CK. 1992. Rock slope failure and debris flow, Gleann na Guiseran, Knoydart. Scottish Journal of Geology 28: 77-80.

Ballantyne CK. 1997. Holocene rock-slope failures in the Scottish Highlands. Paläoklimaforschung 19: 197-206.

Ballantyne CK. 1999. Maximum altitude of Late Devensian glaciation on the Isle of Mull and Isle of Jura. Scottish Journal of Geology 35: 97-106.

Ballantyne CK. 2002. Paraglacial geomorphology. Quaternary Science Reviews 21: 1935-2017.

Ballantyne CK. 2007. Carn Dubh, Ben Gulabin, Perthshire. In Mass Movements in Great Britain, Cooper R (ed). Geological Conservation Review Series, No. 33, Joint Nature Conservation Committee, Peterborough; 107-111.

Ballantyne CK. 2010. Extent and deglacial chronology of the last British-Irish ice sheet: implications of exposure dating using cosmogenic isotopes. Journal of Quaternary Science 25: 515-534. DOI:10.1002/jqs.1310.

Ballantyne CK 2013. Lateglacial rock-slope failures in the Scottish Highlands. Scottish Geographical Journal 129: 67-84. DOI: 10.1080/14702541.2013.781210.

Ballantyne CK, Harris C. 1994. The Periglaciation of Great Britain. Cambridge University Press: Cambridge.

Ballantyne CK, Stone JO. 2009. Rock-slope failure at Baosbheinn, Wester Ross, NW Scotland: age and interpretation. Scottish Journal of Geology 45: 177-181. DOI: 10.114/0036-9276/01-388.

Ballantyne CK, Stone JO. 2012. Did large ice caps persist on low ground in north-west 
Scotland during the Lateglacial Interstade? Journal of Quaternary Science 27: 297306. DOI: $10.1002 / j q s .1544$.

Ballantyne CK, Stone JO. 2013. Timing and periodicity of paraglacial rock-slope failures in the Scottish Highlands. Geomorphology 186: 150-161. DOI: 10.1016/j.geomorph.2012.12.030.

Ballantyne CK, Stone JO, Fifield LK. 1998. Cosmogenic Cl-36 dating of postglacial landsliding at The Storr, Isle of Skye, Scotland. The Holocene 8: 347-351.

Ballantyne CK, Wilson P, Schnabel C, Xu S. 2013. Lateglacial rock-slope failures in NW Ireland: age, causes and implications. Journal of Quaternary Science (in press).

Barnard P, Owen LA, Sharma MC, Finkel RC. 2001. Natural and human-induced landsliding in the Garhwal Himalaya of northern India. Geomorphology 40: 21-35.

Bigot-Cormier F, Braucher R, Bourlès D, Guglielmi Y, Dubar M, Stéphan J-F. 2005. Chronological constraints on processes leading to large landslides. Earth and Planetary Science Letters 235: 141-150. DOI: 10.1016/j.epsI.2005.03.012.

Blikra LH, Longva O, Braathen A, Dehls JF, Stalsberg K. 2006. Rock slope failures in Norwegian Fjord areas: examples, spatial distribution and temporal pattern. In Landslides from massive rock slope failure, Evans SG, Mugnozza GS, Strom A, Hermanns RL. (eds). Springer, Dordrecht, 475-496.

Brideau M-A, Yan M, Stead D. 2009. The role of tectonic damage and brittle rock failure in the development of large rock failures. Geomorphology 103: 30-49. DOI: 10.1016/j.geomorph.2008.04.010.

Brooks SJ, Birks HJB. 2000. Chironomid-inferred Late-glacial air temperatures at Whitrig Bog, southeast Scotland. Journal of Quaternary Science 15: 759-764.

Brooks SJ, Matthews IP, Birks HH, Birks HJB. 2012. High resolution Lateglacial and early-Holocene summer air temperature records from Scotland inferred from chironomid assemblages. Quaternary Science Reviews 41: 67-82. DOI: 10.1016.quascirev.2012.03.007.

Child D, Elliott G, Mifsud C, Smith A, Fink D. 2000. Sample processing for earth science studies at ANTARES. Nuclear Instruments and Methods in Physics Research B172: 856-860. 
Clark CD, Hughes ALC, Greenwood SL, Jordan C, Sejrup HP. 2012. Pattern and timing of retreat of the last British-Irish Ice Sheet. Quaternary Science Reviews 44: 112-146. DOI: 10.1016/j.quascirev.2010.07.019.

Cossart E, Braucher R, Fort M, Bourlès DL, Carcaillet J. 2008. Slope instability in relation to glacial debuttressing in alpine areas (Upper Durance catchment, southeastern France): evidence from field data and ${ }^{10} \mathrm{Be}$ cosmic ray exposure ages. Geomorphology 95: 3-26. DOI:10.1016/j.geomorph.2006.12.022.

Cossart E, Mercier D, Decaulne A, Feuillet T, Jónsson HP, Sæmundsson, P. 2013. Impacts of post-glacial rebound on landslide spatial distribution at a regional scale in northern Iceland (Skagafjörður). Earth Surface Processes and Landforms. DOI: 10.1002/esp.3450.

Cruden D, Hu XQ. 1993. Exhaustion and steady state models for predicting landslide hazards in the Canadian Rocky Mountains. Geomorphology 8: 279-285.

Davenport CA, Ringrose PS. 1987. Deformation of Scottish Quaternary sediment sequences by strong earthquake motions. Geological Society Special Publication 29: 299-314.

Davenport CA, Ringrose PS, Becker A, Hancock P, Fenton C. 1989. Geological investigations of Late- and Postglacial earthquake activity in Scotland. In Earthquakes at North Atlantic passive margins: neotectonics and postglacial rebound, Gregersen S, Basham P. (eds.) Kluwer, Dordrecht, 175-194.

Davies MCR, Hamza O, Harris C. 2001. The effect of rise in mean annual temperature on the stability of rock slopes containing ice-filled discontinuities. Permafrost and Periglacial Processes 12: 137-144.

Dawson AG. 1977. A fossil rock glacier in Jura. Scottish Journal of Geology 13: 3741.

Dawson AG. 1979. A Devensian medial moraine in Jura. Scottish Journal of Geology 15: 43-48.

Dortch JM, Owen LA, Haneberg WC, Caffee MW, Dietsch C, Kamp U, 2009. Nature and timing of large landslides in the Himalaya and Transhimalaya of northern India. Quaternary Science Reviews 28: 1037-1054. DOI: 10.1016/quascirev.2008.05.002.

Eberhardt E, Stead D, Coggan JS. 2004. Numerical analysis of initiation and 
progressive failure in natural rock slopes - the 1991 Randa rockslide. International Journal of Rock Mechanics and Mining Science 41: 69-87.

El Bedoui S, Gugliemi Y, Lebourg T, Pérez J-L. 2009. Deep-seated failure propagation in a fractured rock slope over 10,000 years: the La Clapière slope, the south-eastern French Alps. Geomorphology 105: 232-238. DOI: 10.1016/j.geomorph.2008.0.025.

Evans SG, Clague JJ. 1994. Recent climate change and catastrophic geomorphic processes in mountain environments. Geomorphology 10: 107-128.

Fabel D, Ballantyne CK, Xu S. 2012. Trimlines, blockfields, mountain-top erratics and the vertical dimensions of the last British-Irish Ice Sheet in NW Scotland. Quaternary Science Reviews 55: 91-102. DOI: 10.1016/j.quascirev.2012.09.002.

Fauqué L, Hermanns RL, Hewitt K, Rosas M, Wilson C, Baumann V, Lagorio S, Di Tommaso I. 2009. Mega-deslizamientos de la pared sur del Cerro Aconcagua y su relación con depósitos asignados a la glaciación Pleistocena. Revista de la Asociación Geológica Argentina 65: 691-712.

Fenton $\mathrm{CH}$ (ed). 1992. Neotectonics in Scotland: a field guide. University of Glasgow: Glasgow.

Finlayson A, Golledge N, Bradwell T, Fabel D. 2011. Evolution of a Lateglacial mountain icecap in northern Scotland. Boreas 40: 536-554. DOI: 10.111/j.15023885.2010.00202.x.

Firth CR, Stewart IS. 2000. Postglacial tectonics of the Scottish glacio-isostatic uplift centre. Quaternary Science Reviews 19: 1469-1493.

Golledge NR. 2010. Glaciation of Scotland during the Younger Dryas Stadial: a review. Journal of Quaternary Science 25: 550-566. DOI: 10.1002/jqs.1319.

Gregerson S, Basham PW. (eds.) 1989. Earthquakes at North Atlantic passive margins: neotectonics and postglacial rebound. Kluewer: Dordrecht.

Gruber S, Haeberli W. 2007. Permafrost in steep bedrock slopes and its temperaturerelated destabilization following climate change. Journal of Geophysical Research 112: F02S18. DOI: 10.1029/2006JF000547.

Gugliemi Y, Cappa F. 2010. Regional-scale relief evolution and large landslides: insights from geomechanical analyses in the Tinée Valley (southern French Alps). 


\section{Geomorphology 117: 121-129. DOI: j.geomorph.2009.11.016.}

Haeberli W, Wegmann M, Vonder MühII D. 2008. Slope stability problems related to glacier shrinkage and permafrost degradation in the Alps. Eclogae Geologicae Helvetiae 90: 407-414.

Hermanns RL, Niedermann, S. 2011. Late Pleistocene-early Holocene palaeoseismicity deduced from lake sediment deformation and coeval landsliding in the Calchaquíes valleys, NW Argentina. Geological Society of America Special Paper 479: 181-194. DOI: 10.1130/2011.2479(08).

Hermanns RL, Schellenberger, A. 2008. Quaternary tephrochronology helps define conditioning factors and triggering mechanisms of rock avalanches in NW Argentina. Quaternary International 178: 261-275. DOI: 10.1016/j.quaint.2007.05.002.

Hermanns RL, Redfield TF, Bunkholt HSS, Fischer L, Oppikofer T. 2012. Cosmogenic nuclide dating of slow-moving rockslides in Norway in order to assess long-term slide velocities. In Landslides and engineered slopes: protecting society through improved understanding, Eberhardt E, Froese C, Turner K, Leroueil S (eds). CRC Press: Boca Raton; 84-854.

Hewitt K, Clague JJ, Orwin, JF. 2008. Legacies of catastrophic rock slope failures in mountain landscapes. Earth-Science Reviews 87: 1-38. DOI: 10.1016/j.earscirev.2007.10.1002.

Hewitt K, Gosse J, Clague JJ. 2011. Rock avalanches and the pace of Late Quaternary development of river valleys in the Karakoram Himalaya. Geological Society of America Bulletin 123: 1836-1850. DOI: 10.1130/B30341.1.

Hencher SR, Lee SG, Carter TG, Richards LR. 2011. Sheeting joints: characterisation, shear strength and engineering. Rock Mechanics and Rock Engineering 44: 1-22. DOI: 10.1007/s00603-010-0100-y.

Heyman J, Stroeven AP, Harbor JM, Caffee MW. 2011. Too young or too old: evaluating cosmogenic exposure dating based on an analysis of compiled boulder exposure ages. Earth and Planetary Science Letters 302: 71-80. DOI: 10.1016/j.epsl.2010.11.040.

Hippolyte J-C, Bourlès D, Braucher R, Carcaillet J, Léanni L, Arnold M, Aumaître G. 2009. Cosmogenic ${ }^{10} \mathrm{Be}$ dating of a sackung and its faulted rock glaciers, in the 
Alps of Savoy (France). Geomorphology 108: 312-320. DOI: 10.1016/j.geomorph.200.02.024.

Hormes A, Ivy-Ochs S, Kubik PW, Ferreli L, Michetti AM. 2008. ${ }^{10}$ Be exposure ages of a rock avalanche and a late glacial moraine in the Alta Valtellina, Italian Alps. Quaternary International 190: 136-145. DOI: 10.1016/j.quaint.2007.06.036.

Hubbard A, Bradwell T, Golledge NR, Hall AM, Patton H, Sugden DE, Cooper R, Stoker MS. 2009. Dynamic cycles, ice streams and their impact on the extent, chronology and deglaciation of the British-Irish Ice Sheet. Quaternary Science Reviews 28: 758-776. DOI: 10.1016/j.quascirev.2008.12.026.

Ivy-Ochs, S., Schaller, M., 2010. Examining processes and rates of landscape change with cosmogenic radionuclides. Radioactivity in the Environment 16: 231-294.

Ivy-Ochs, S., Poschinger, A.V., Synal, H-A., Maisch, M., 2009. Surface exposure dating of the Flims landslide, Graubünden, Switzerland. Geomorphology 103: 104112. DOI: 10.1016/j.geomorph.2007.10.024.

Jarman D. 2006. Large rock-slope failures in the Highlands of Scotland: characterisation, causes and spatial distribution. Engineering Geology 83: 161-182. DOI: 10.1016/j.enggeo.2005.06.030.

Jarman D, Wilson P, Harrison S. 2013. Are there any relict rock glaciers in the British mountains? Journal of Quaternary Science 28: 131-143. DOI: 10.1002/jqs.2574.

Kaplan MR, Schaefer JM, Denton GH, Barrell DJA, Chinn TJH, Putnam AE, Andersen BG, Finkel RC, Schwartz R, Doughty AM. 2010. Glacier retreat in New Zealand during the Younger Dryas stadial. Nature 467: 194-197. DOI: 10.1038/nature09313.

Kemeny J. 2003. The time-dependent reduction of sliding cohesion due to rock bridges along discontinuities: a fracture mechanics approach. Rock Mechanics and Rock Engineering 36: 27-38.

Kohl C, Nishiizumi K. 1992. Chemical isolation of quartz for measurement of in situproduced cosmogenic nuclides. Geochimica et Cosmochimica Acta 56: 3586-3587.

Krautblatter M, Funk D, Günzel FK. 2013. Why permafrost rocks become unstable: a rock-ice-mechanical model in space and time. Earth Surface Processes and Landforms DOI: 10.1002/esp3374. 
Krautblatter M, Huggel C, Deline P, Hasler A. 2012. Research perspectives on unstable high-alpine bedrock permafrost: measurement, modelling and process understanding. Permafrost and Periglacial Processes 23: 80-88. DOI: 10.1002/ppp.740.

Lagerbäck, R. 1992. Dating of Late Quaternary faulting in northern Sweden. Journal of the Geological Society, London 149: 285-291.

Lal D. 1991. Cosmic ray labeling of erosion surfaces: in situ nuclide production rates and erosion models. Earth and Planetary Science Letters 104: 424-439.

Leith K, Amann F, Moore JR, Kos A, Loew S. 2010. Conceptual modelling of nearsurface extensional fracture in the Matter and Saas Valleys, Switzerland. In Geologically Active. Proceedings of the 11th IAEG Congress, Auckland, New Zealand, Williams AL, Pinches GM, Chin CY, McMorran TJ, Massey Cl (eds). CRC Press, Boca Raton; 363-371.

Leith K, Moore J, Amann F, Loew S. 2011. Effect of glacial ice cover on fracturing critically stressed bedrock. Geophysical Research Abstracts 13: EGU2011-128252.

Longva O, Blikra LH, Dehls JF. 2009. Rock avalanches: distribution and frequencies in the inner part of Storfjorden, Møre og Romsdal County, Norway. Geological Survey of Norway, Report 2009.002, 32 pp.

Lowe JJ, Rasmusson SO, Björk S, Hoek WJ, Steffensen JP, Walker MJC, Yu ZC, INTIMATE Group. 2008. Synchronisation of palaeoenvironmental events in the North Atlantic region during the Last Termination: a revised protocol recommended by the INTIMATE Group. Quaternary Science Reviews 27: 6-17. DOI: 10.1016/j.quascirev.2007.09.016.

MacLeod A, Palmer AP., Lowe JJ, Rose J, Bryant C., Merritt J. 2011. Timing of glacier response to Younger Dryas climatic cooling in Scotland. Global and Planetary Change 79: 264-274. DOI: 10.1016/j.gloplacha.2010.07.006.

McColl ST. 2012. Paraglacial rock-slope stability. Geomorphology 153-154: 1-16. DOI: 10.1016/j.geomorph.2012.02.015.

Mercier D., Cossart E., Decaulne A, Feuillet T, Jónsson HP, Sæmundsson P. 2013. The Höfðahólar rock avalanche (sturzstrom): chronological constraint of paraglacial 
landsliding on an Icelandic hillslope. The Holocene 23: 432-446. DOI: 10.1177/0959683612463014.

Mitchell WA, McSaveney MJ, Zundervan A, Kim K, Dunning SA, Taylor PJ. 2007. The Keylong Serai rock avalanche, NW Indian Himalaya: geomorphology and palaeoseismic implications. Landslides 4: 245-254. DOI: 10.1007/s10346-0070085-0.

Mörner N-A. 1991. Intense earthquakes and seismotectonics as a function of glacial isostasy. Tectonophysics 188: 407-410.

Mörner N-A. 2004. Active faults and palaeoseismicity in Fennoscandia, especially Sweden. Primary structure and secondary effects. Tectonophysics 380: 139-157. DOI: 10.1016/j.tecto.2003.09.015.

Mörner N-A. 2005. An interpretation and catalogue of palaeoseismicity in Sweden. Tectonophysics 408: 265-307. DOI: 10.1016/j.tecto.2005.05.039.

Mörner, N-A, Tröften PE, Sjöberg R, Grant D, Dawson S, Bronge C, Kvamsdal O, Sidén A. 2000. Deglacial palaeoseismicity in Sweden: the 9663 BP Iggesund event. Quaternary Science Reviews 19: 1461-1468.

Muir-Wood R. 2000. Deglaciation seismotectonics: a principal influence on intraplate seismogenesis at high latitudes. Quaternary Science Reviews 19: 1399-1411.

Musson RMW. 2007. British earthquakes. Proceedings of the Geologists' Association 118: 305-337.

Nishiizumi K, Imamura M, Caffee M, Southon JR, Finkel RC, McAninch J. 2007. Absolute calibration of ${ }^{10} \mathrm{Be}$ AMS standards. Nuclear Instruments and Methods B258: 403-413. DOI: 10.1016/j.nimb.2007.01.297.

Peacock JD. 2008. Late Devensian palaeoenvironmental changes in the sea area adjacent to Islay, SW Scotland: implications for deglacial history of the island. Scottish Journal of Geology 44: 183-190. DOI:

Penna IM, Hermanns RL, Niedermann S, Folguera A. 2011. Multiple slope failures associated with neotectonic activity in the Southern Central Andes ( $\left.37^{\circ}-37^{\circ} 30^{\prime} S\right)$, Patagonia, Argentina. Geological Society of America, Bulletin 123: 1880-1895. DOI: $10.1130 /$ B30399.1.

Prager C, Ivy-Ochs S, Ostermann M, Synal H-A, Patzelt G. 2008. Geology and 
radiometric $14 \mathrm{C}-, 36 \mathrm{Cl}$ - and Th-/U-dating of the Fernpass rockslide (Tyrol, Austria). Geomorphology 103: 93-103. DOI:10.1016/j.geomorph.2007.10.018.

Putkonen J, Swanson T. 2003. Accuracy of cosmogenic dates for moraines. Quaternary Research 59: 255-261.

Rasmussen SO, Andersen KK, Svensson AM, Steffensen JP, Vinther BM, Clausen $H B$, Siggaard-Andersen ML, Johnsen SJ, Larsen LB, Dahl-Jensen D, Bigler $M$, Rothlisberger R, Fischer H, Goto-Azuma K, Hansson ME, Ruth U. 2006. A new Greenland ice core chronology for the last glacial termination. Journal of Geophysical Research 111: D06102. DOI: 10.1029/2005JD006079.

Ringrose PS. 1989a. Recent fault movement and palaeoseismicity in western Scotland. Tectonophysics 163: 305-314.

Ringrose PS. 1989b. Palaeoseismic (?) liquifaction event in late Quaternary lake sediments at Glen Rpy, Scotland. Terra Nova 1: 57-62.

Ringrose PS, Hancock P, Fenton C, Davenport CA. 1991. Quaternary tectonic activity in Scotland. Geological Society Engineering Geology Special Publication 7: 679686.

Sanchez G, Rolland Y, Corsini M, Braucher R, Bourlès D, Arnold M, Aumaître G. 2010. Relationships between tectonics, slope instability and climate change: cosmic ray exposure dating of active faults, landslides and glacial surfaces in the French Alps. Geomorphology 117: 1-13. DOI: 10.1016/j.geomorph.200.10.019.

Sanhueza-Pino K, Korup O, Hetzel R, Munack H, Weidinger JT, Dunning S, Ormukov C, Kubik PW. 2011. Glacial advances constrained by ${ }^{10} \mathrm{Be}$ exposure dating of bedrock landslides, Kyrgyz Tien Shan. Quaternary Research 76: 295-304. DOI: 10.1016/j.yqres.2011.06.013.

Seong YB, Bishop MP, Bush A, Clendon P, Copland L, Finkel RC, Kamp U, Owen LA, Schroder, JF. 2009. Landforms and landscape evolution in the Skardu, Shigar and Braldu Valleys, Central Karakoram. Geomorphology 103: 251-267. DOI: 10.1016/j.geomorph.2008.04.026.

Shennan I, Innes JB, Long AJ, Zong Y. 1995. Late Devensian and Holocene relative sea-level changes in northwest Scotland: new data to test existing models. Quaternary International 26: 97-123. 
959

960

961

962

963

964

965

966

967

968

Shroder JF, Owen LA, Seong YB, Bishop MP, Bush A, Caffee MW, Copland L, Finkel RC, Kamp U. 2011. The role of mass movements on landscape evolution in the central Karakoram: discussion and speculation. Quaternary International 236: 3447. DOI: 10.1016/j.quaint.2010.05.024.

Sissons JB, Cornish R. 1982a. Rapid localised glacio-isostatic uplift at Glen Roy, Scotland. Nature 297: 213-215.

Sissons JB, Cornish R. 1982b. Differential glacio-isostatic uplift of crustal blocks at Glen Roy, Scotland. Quaternary Research 18: 268-288.

Smith DE, Stewart IS, Harrison S., Firth CR. 2009. Late Quaternary neotectonics and mass movement in South East Raasay, Inner Hebrides, Scotland. Proceedings of the Geologists' Association 120: 145-154. DOI: 10.1016/j.pgeola.2009.08.006.

Soldati M, Corsini A, Pasuto A. 2004. Landslides and climate change in the Italian Dolomites since the Late glacial. Catena 55: 141-161. DOI: 10.1016/S03418162(03)00113-9.

Stewart IS, Firth CR, Rust DJ, Collins PEF, Firth JA. 2001. Postglacial fault movement and palaeoseismicity in western Scotland: a reappraisal of the Kinloch Hourn fault, Kintail. Journal of Seismology 6: 307-328.

Stewart IS, Sauber J, Rose J. 2000. Glacio-seismotectonics: ice sheets, crustal deformation and seismicity. Quaternary Science Reviews 19: 1367-1389.

Stock GM, Uhrhammer RA. 2010. Catastrophic rock avalanche 3600 years BP from El Capitan, Yosemite Valley, California. Earth Surface Processes and Landforms 35: 941-951. DOI:10.1002/esp.1982.

Stone JO. 2000. Air pressure and cosmogenic isotope production. Journal of Geophysical Research 105 (B10): 23753-23759.

Walker F. 1961. The Islay-Jura Dyke swarm. Transactions of the Geological Society of Glasgow 24: 121-137.

Welkner D, Eberhardt E, Hermanns RL. 2010. Hazard investigation of the Portillo Rock Avalanche site, central Andes, Chile, using an integrated field mapping and numerical modelling approach. Engineering Geology 114: 278-297. DOI: 10.1016/j.enggeo.2010.05.007.

Wilson P. 2004. Relict rock glaciers, slope failure deposits or polygenetic landforms? 
990 A reassessment of some Donegal debris landforms. Irish Geography 37: 77-87.

991 Xu S, Dougans AB, Freeman SPHT, Schnabel C, Wilcken KM. 2010. Improved Be-10

992 and Al-26 AMS with a 5 MV spectrometer. Nuclear Instruments and Methods B268:

993 736-738. DOI: 10.1016/j.nimb.2009.10.018. 
994

995

996

997

998

999

1000

1001

1002

1003

1004

1005

1006

1007

1008

1009

1010

1011

1012

1013

1014

1015

1016

1017

1018

1019

1020

1021

1022

1023

1024

1025

1026

1027

1028

1029

\section{Captions to Figures}

Figure 1. The Paps of Jura, showing locations of RSF runout deposits and boulders sampled for ${ }^{10} \mathrm{Be}$ surface exposure dating. BOE: Beinn an Oir East RSF. BS: Beinn Shiantaidh RSF. BCW: Beinn a'Chaolais West RSF. BCE: Beinn a'Chaolais East RSF. BCS: Beinn a'Chaolais South RSF.

Figure 2. Sampled rock-slope failures. (a) Beinn Shiantaidh RSF; the failure scar is at the crest of the slope. (b) Beinn Shiantaidh RSF, showing the conspicuous arcuate outer ridge. (c) Beinn a'Chaolais South RSF runout lobe. The slope behind the runout lobe has apparently experienced deep-seated gravitational deformation. (d) Beinn a'Chaolais East RSF runout lobe. (e) Bouldery runout lobes of the Beinn a'Chaolais West RSF; samples were obtained from the lobe on the left. (f) Beinn an Oir East RSF.

Figure 3. Examples of sampled boulders. (a) Sample BS-06, Beinn Shiantaidh RSF. (b) Sample BCS-02, Beinn a'Chaolais South RSF. (3) Sample BCE-03, Beinn a'Chaolais East RSF. (4) Sample BOE-05, Beinn an Oir East RSF. Samples were obtained from the top surfaces of boulders. The hammer is $30 \mathrm{~cm}$ long.

Figure 4. The Sgriob na Caillich medial moraine. (a) Looking ESE towards Beinn an Oir. The arrow points to the failure scar of the RSF that appears to have provided the source of the debris on the moraine. (b) Looking WNW, and showing the bouldery, low relief nature of the moraine.

Figure 5. Exposure ages obtained for the five RSFs on Jura (vertical dashes). Top: ages calibrated using LL LPR. Bottom: ages calibrated using NWH11.6 LPR. Bars represent $\pm 1 \sigma$ total uncertainty. The vertical line represents the weighted mean deglaciation age and the shaded area represents the associated $\pm 1 \sigma$ uncertainty. Asterisked $\left(^{*}\right)$ samples are anomalous outliers that significantly pre-date deglaciation or differ significantly from two other ages obtained from the same site.

Figure 6 Top: Probability density distributions (PDDs) of the exposure ages obtained for the Scriob na Caillich moraine and the five RSFs on Jura, excluding outliers in both cases. Bottom: PDDs of the time elapsed since deglaciation based on PDDs shown on top. Left: ages calibrated using LL LPR. Right: ages calibrated using 
1030 NWH11.6 LPR. The darker shaded zone represents $\pm 1 \sigma$ and the lighter shaded zone 1031 represents $\pm 2 \sigma$, demonstrating that all ages post-date the timing of deglaciation $1032 \quad(t=0)$ at $95 \%$ confidence.

1033.

1034 Figure 7. Uncertainty-weighted mean ages for three Jura RSF runout deposit (BS, $1035 \mathrm{BCS}, \mathrm{BCE})$ and all postglacial ages for the remaining two (BCW, BOE) plotted 1036 against: (1) crustal uplift rates for Arisaig (from Firth and Stewart, 2000); (2) the timing 1037 of deglaciation of Jura (this study); (3) NGRIP ice core $\delta^{18} \mathrm{O}$ data for 7-18 ka 1038 (Rasmussen et al., 2006); (4) the ice core stages proposed by Lowe et al. (2008); and 1039 (5) mean July temperature data inferred from chironomid assemblages in SE Scotland 1040 (Brooks and Birks, 2000), matched to the NGRIP ice core data. Solid circles represent 1041 ages calculated using LL LPR, and vertical dashes represent ages calculated using 1042 NWH11.6 LPR. Solid horizontal lines represent $\pm 1 \sigma$ external uncertainties for the 1043 weighted mean ages (BS, BCS, BCE) and the most probable individual ages for BCW 1044 and BOE. Dashed horizontal lines represent $\pm 1 \sigma$ external uncertainties for the 1045 younger ages obtained for BCW and BOE. 
1046 Table 1: Sample locations and analytical details

\begin{tabular}{|c|c|c|c|c|c|c|c|c|c|}
\hline Sample & AMS ID & Grid reference & $\begin{array}{l}\text { Latitude } \\
\left({ }^{\circ} \mathrm{N}\right)\end{array}$ & $\begin{array}{c}\text { Longitude } \\
\left({ }^{\circ} \mathrm{W}\right)\end{array}$ & $\begin{array}{l}\text { Altitude } \\
(\mathrm{m})\end{array}$ & $\begin{array}{l}\text { Thickness } \\
(\mathrm{mm})\end{array}$ & $\begin{array}{l}\text { Density } \\
\left(\mathrm{g} \mathrm{cm}^{3}{ }^{3}\right)\end{array}$ & $\begin{array}{l}\text { Shielding } \\
\text { correction }\end{array}$ & $\begin{array}{c}{ }^{10} \mathrm{Be} \\
\text { atoms } \mathrm{g}^{-1} \text { (quartz) }\end{array}$ \\
\hline \multicolumn{10}{|c|}{ Sgriob na Caillich medial moraine } \\
\hline SNC-02 & b6534 & NR 488754 & 55.9063 & 06.0196 & 374 & 38 & 2.75 & 0.998 & $80594 \pm 8846$ \\
\hline SNC-03 & b6535 & NR 487754 & 55.9062 & 06.0207 & 363 & 39 & 2.67 & 0.998 & $70486 \pm 7288$ \\
\hline SNC-06 & b6637 & NR 482758 & 55.9093 & 06.0304 & 356 & 35 & 2.66 & 0.999 & $95643 \pm 4334$ \\
\hline SNC-07 & b6638 & NR 481758 & 55.9092 & 06.0307 & 353 & 40 & 2.66 & 0.999 & $94685 \pm 3698$ \\
\hline \multicolumn{10}{|c|}{ Beinn Shiantaidh (BS) RSF } \\
\hline BS-01 & b5160 & NR 521748 & 55.9032 & 05.9659 & 383 & 15 & 2.65 & 0.984 & $88483 \pm 3238$ \\
\hline BS-03 & b5163 & NR 521748 & 55.9034 & 05.9676 & 401 & 30 & 2.65 & 0.982 & $94096 \pm 3428$ \\
\hline BS-06 & b5164 & NR 521747 & 55.9023 & 05.9652 & 382 & 27 & 2.70 & 0.989 & $86712 \pm 3297$ \\
\hline \multicolumn{10}{|c|}{ Beinn a'Chaolais West (BCW) RSF } \\
\hline BCW-01 & b5157 & NR 482734 & 55.8875 & 06.0273 & 400 & 24 & 2.64 & 0.973 & $70385 \pm 2612$ \\
\hline BCW-03 & b5158 & NR 482734 & 55.8874 & 06.0269 & 410 & 29 & 2.65 & 0.972 & $58891 \pm 2302$ \\
\hline BCW-04 & b5159 & NR 482733 & 55.8872 & 06.0269 & 408 & 24 & 2.71 & 0.972 & $89920 \pm 3322$ \\
\hline \multicolumn{10}{|c|}{ Beinn a'Chaolais South (BCS) RSF } \\
\hline BCS-01 & b5154 & NR 489727 & 55.8820 & 06.0163 & 402 & 36 & 2.69 & 0.977 & $83374 \pm 2961$ \\
\hline BCS-02 & b5155 & NR 489727 & 55.8820 & 06.0163 & 400 & 33 & 2.65 & 0.977 & $90274 \pm 3310$ \\
\hline BCS-04 & b5550 & NR 489728 & 55.8824 & 06.0164 & 418 & 26 & 2.65 & 0.977 & $83677 \pm 3327$ \\
\hline \multicolumn{10}{|c|}{ Beinn a'Chaolais East (BCE) RSF } \\
\hline BCE-02 & b5148 & NR 493731 & 55.8859 & 06.0102 & 440 & 52 & 2.67 & 0.974 & $56806 \pm 2177$ \\
\hline BCE-03 & b5152 & NR 493731 & 55.8855 & 06.0100 & 428 & 33 & 2.65 & 0.982 & $83349 \pm 3181$ \\
\hline BCE-04 & b5153 & NR 493730 & 55.8852 & 06.0101 & 421 & 40 & 2.67 & 0.977 & $79113 \pm 2992$ \\
\hline \multicolumn{10}{|c|}{ Beinn an Oir East (BOE) RSF } \\
\hline BOE-03 & b5554 & NR 503746 & 55.9001 & 05.9952 & 482 & 60 & 2.66 & 0.962 & $123328 \pm 7195$ \\
\hline BOE-04 & b5555 & NR 503746 & 55.8999 & 05.9948 & 470 & 37 & 2.68 & 0.976 & $52963 \pm 2084$ \\
\hline BOE-05 & b5556 & NR 503746 & 55.8999 & 05.9948 & 469 & 11 & 2.66 & 0.976 & $90402 \pm 3610$ \\
\hline
\end{tabular}


Table $2{ }^{10} \mathrm{Be}$ exposure ages

\begin{tabular}{|c|c|c|c|c|c|c|}
\hline \multirow[t]{2}{*}{ Sample } & \multicolumn{3}{|c|}{ LL LPR } & \multicolumn{3}{|c|}{ NWH 11.6 LPR } \\
\hline & $\begin{array}{l}\text { Exposure } \\
\text { age (ka) }\end{array}$ & $\begin{array}{c}\text { Internal } \\
\text { uncertainty } \\
\text { (ka) }\end{array}$ & $\begin{array}{c}\text { Total } \\
\text { uncertainty } \\
(\mathrm{ka})\end{array}$ & $\begin{array}{l}\text { Exposure } \\
\text { age (ka) }\end{array}$ & $\begin{array}{c}\text { Internal } \\
\text { uncertainty } \\
\text { (ka) }\end{array}$ & $\begin{array}{c}\text { Total } \\
\text { uncertaint } \\
\text { (ka) }\end{array}$ \\
\hline \multicolumn{7}{|c|}{ Scriob na Caillich moraine } \\
\hline SNC-02* & 14.01 & 1.56 & 1.69 & 13.10 & 1.46 & 1.53 \\
\hline SNC-03* & 12.35 & 1.30 & 1.41 & 11.55 & 1.21 & 1.28 \\
\hline SNC-06 & 16.88 & 0.78 & 1.10 & 15.78 & 0.73 & 0.92 \\
\hline SNC-07 & 16.82 & 0.67 & 1.03 & 15.73 & 0.63 & 0.84 \\
\hline Weighted mean & 16.84 & 0.51 & 0.93 & 15.75 & 0.47 & 0.53 \\
\hline
\end{tabular}

Beinn Shiantaidh (BS) RSF

BS-01

BS-03*

BS-06

15.18

19.22

0.56

0.90

15.05

0.71

1.14

Weighted mean

15.11

0.58

0.91

0.41

0.81

\subsection{9}

17.97

0.53

14.08

0.67

0.73

Beinn a'Chaolais South (BCS) RSF

BCS-01

14.39

BCS-02

15.58

0.52

0.84

0.58

0.92

14.10

0.57

0.86

14.66

0.32

0.75

14.14

0.54

0.92

Weighted mean

Beinn a'Chaolais East (BCE) RSF

BCE-02*

BCE-03

9.56

BCE-04

Weighted mean

13.92

0.37

0.57

13.44

0.54

0.84

0.52

0.81

13.67

0.37

0.73

13.45

14.56

0.49

0.54

Beinn a'Chaolais West (BCW) RSF

BCW-01

12.06

BCW-03

10.08

BCW-04

15.37

0.45

0.72

13.19

0.53

0.75

Weighted mean (not calculated)

\section{Beinn an Oir East (BOE) RSF}

BOE-03*

BOE-04

20.57

0.40

0.61

0.58

0.92

13.70

0.30

0.71

BOE-05

8.54

1.23

1.56

0.34

0.52

14.38

0.59

0.88

19.23

1.14

1.33

Weighted mean (not calculated)

13.45

0.55

0.42

* Outlier ages that predate deglaciation or differ at $p<0.05$ from two other consistent ages from the same site; these are excluded from calculation of the uncertainty-weighted mean ages. Scaling from CRONUS online calculator (Balco et al., 2008): wrapper script version 2.2; main calculator version 2.1; constants version 2.2.1; muons version 1.1. Internal uncertainties $( \pm 1 \sigma)$ are analytical uncertainties on ${ }^{10} \mathrm{Be}$ measurements only. Total uncertainties $( \pm 1 \sigma)$ also incorporate uncertainties in calibration and scaling. 
Figure 1. The Paps of Jura, showing locations of RSF runout deposits and boulders sampled for $10 \mathrm{Be}$ surface exposure dating. BOE: Beinn an Oir East RSF. BS: Beinn Shiantaidh RSF. BCW: Beinn a'Chaolais West RSF. BCE: Beinn a'Chaolais East RSF. BCS: Beinn a'Chaolais South RSF. $146 \times 137 \mathrm{~mm}(300 \times 300 \mathrm{DPI})$

BS Beinn Shiantaidh BCS Beinn a' Chaolais South BCE Beinn a' Chaolais East BCW Beinn a' Chaolais West BOE Beinn an Oir East

(-) Crown copyrightddatabase right 2012. An Ordnance SurveylEDINA supplied service,

$$
\begin{aligned}
& \text { RSF runout deposits } \\
& \text { F RSF scar without runout debris } \\
& \text { * Evidence for slope deformation } \\
& \because \because \text {. Medial moraine deposits } \\
& \text { ii Scree }
\end{aligned}
$$$$
\therefore \text { Boulder sample location }
$$

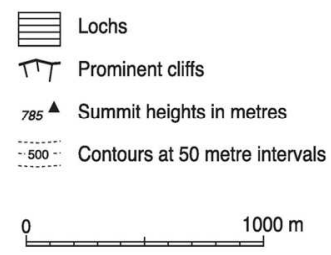



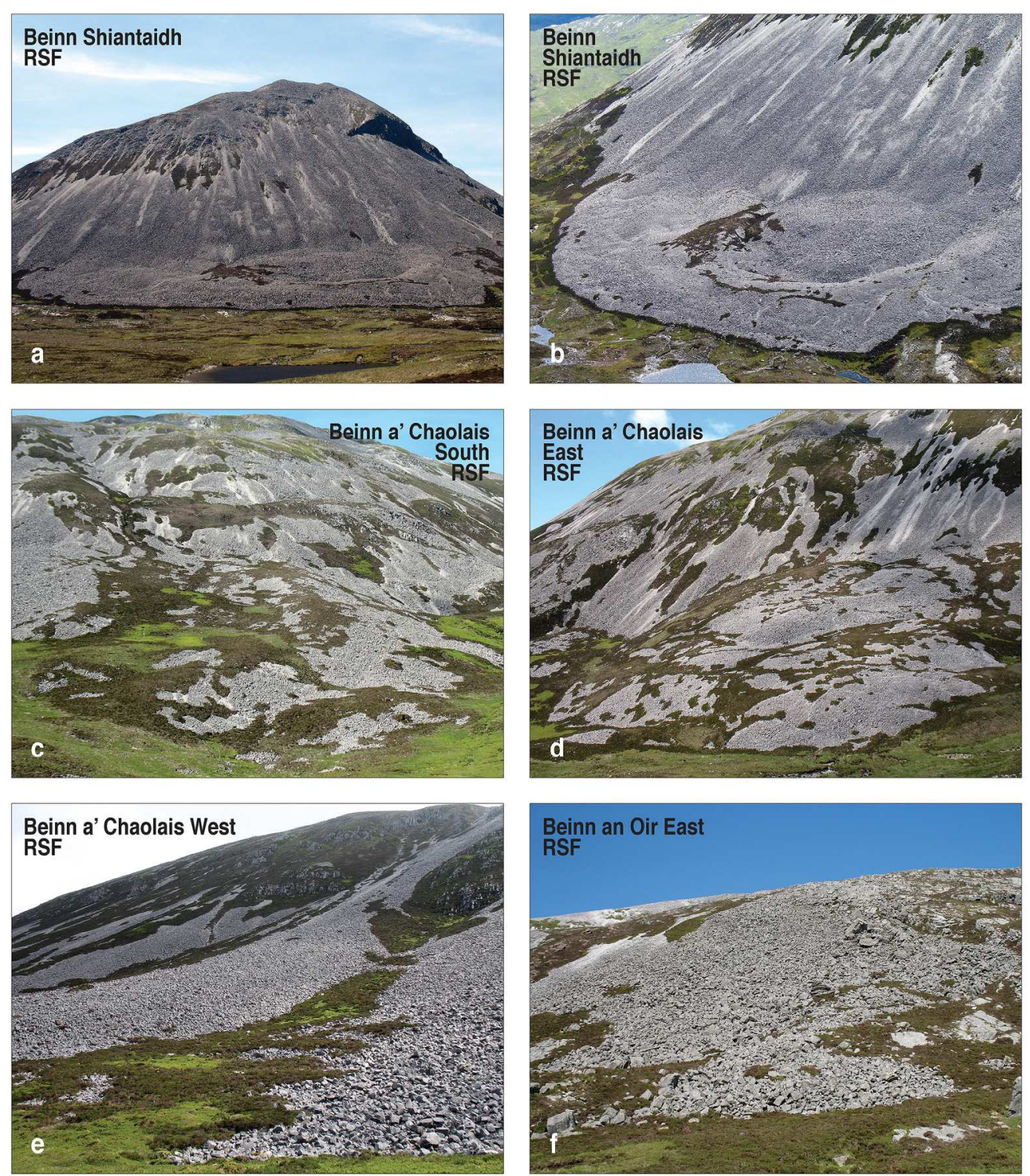

Figure 2. Sampled rock-slope failures. (a) Beinn Shiantaidh RSF; the failure scar is at the crest of the slope. (b) Beinn Shiantaidh RSF, showing the conspicuous arcuate outer ridge. (c) Beinn a'Chaolais South RSF runout lobe. The slope behind the runout lobe has apparently experienced deep-seated gravitational deformation. (d) Beinn a'Chaolais East RSF runout lobe. (e) Bouldery runout lobes of the Beinn a'Chaolais West RSF; samples were obtained from the lobe on the left. (f) Beinn an Oir East RSF. $181 \times 207 \mathrm{~mm}(300 \times 300$ DPI $)$ 

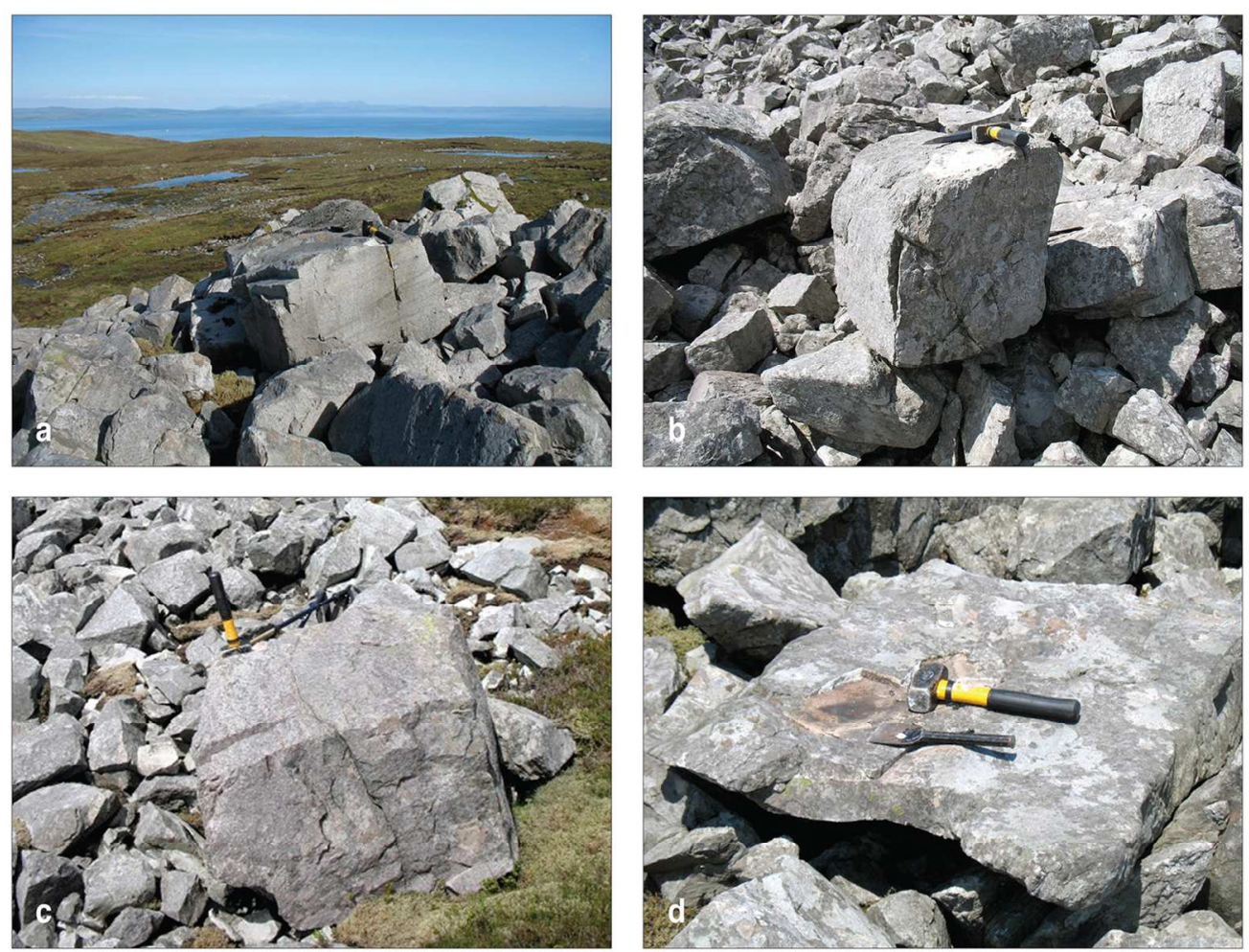

Figure 3. Examples of sampled boulders. (a) Sample BS-06, Beinn Shiantaidh RSF. (b) Sample BCS-02, Beinn a'Chaolais South RSF. (3) Sample BCE-03, Beinn a'Chaolais East RSF. (4) Sample BOE-05, Beinn an Oir East RSF. Samples were obtained from the top surfaces of boulders. The hammer is $30 \mathrm{~cm}$ long. $120 \times 92 \mathrm{~mm}(300 \times 300 \mathrm{DPI})$ 

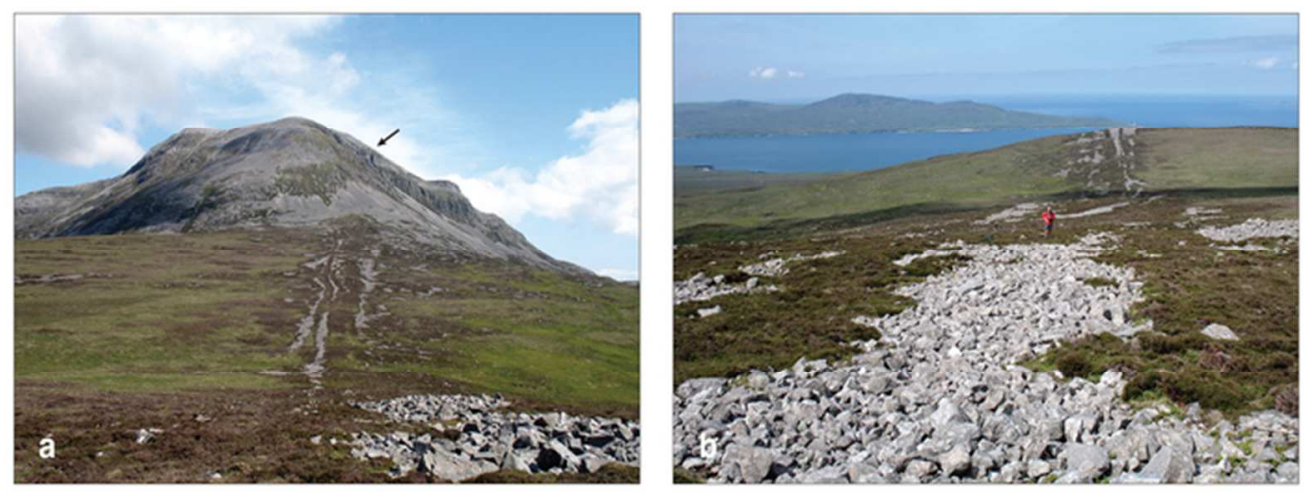

Figure 4. The Sgriob na Caillich medial moraine. (a) Looking ESE towards Beinn an Oir. The arrow points to the failure scar of the RSF that appears to have provided the source of the debris on the moraine. (b) Looking WNW, and showing the bouldery, low relief nature of the moraine.

$59 \times 22 \mathrm{~mm}(300 \times 300 \mathrm{DPI})$ 
1

2

3

4

5

6

7

8

9

10

11

12

13

14

15

16

17

18

19

20

21

22

23

24

25

26

27

28
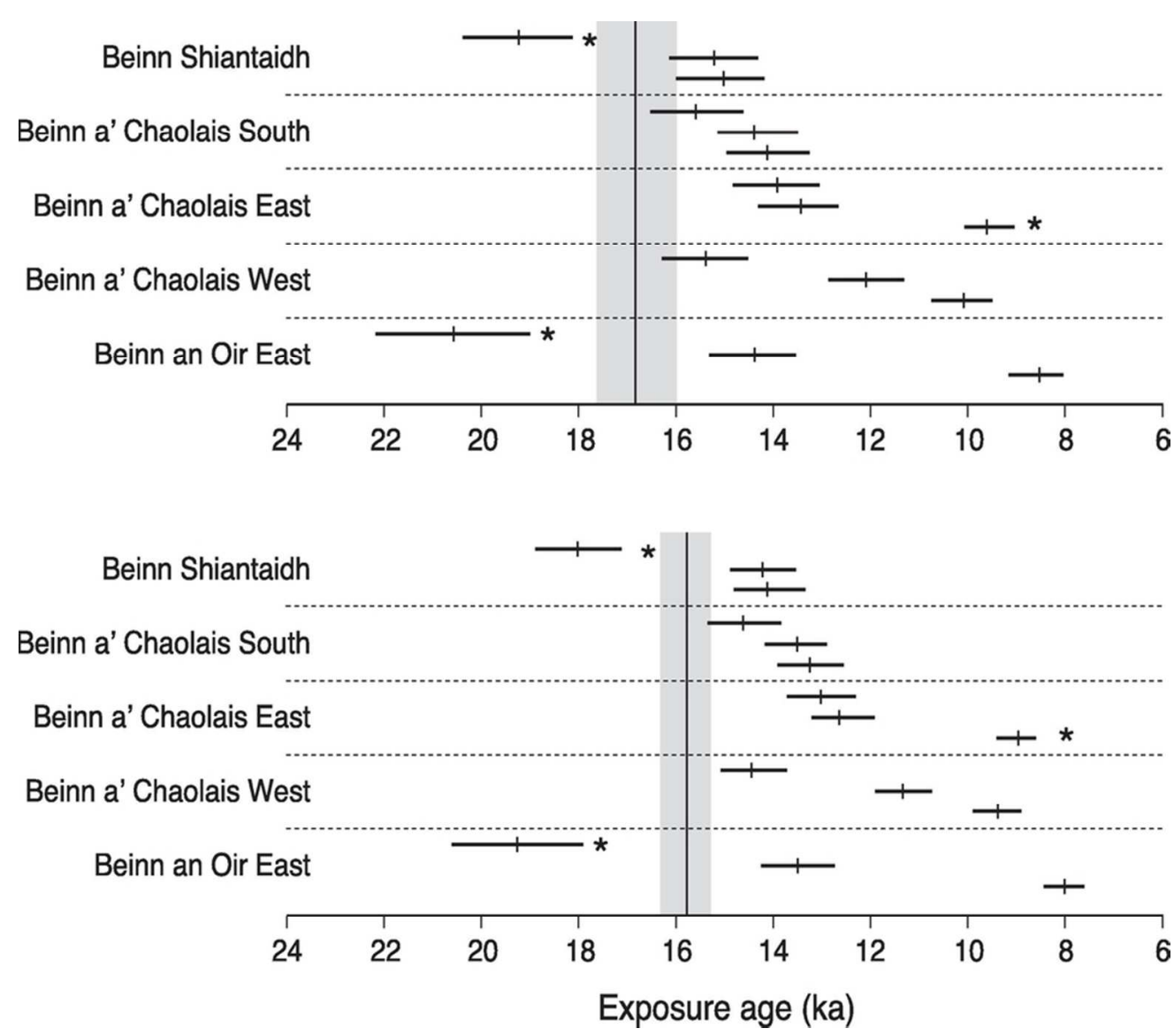

Figure 5. Exposure ages obtained for the five RSFs on Jura (vertical dashes). Top: ages calibrated using LL LPR. Bottom: ages calibrated using NWH11.6 LPR. Bars represent $\pm 1 \sigma$ total uncertainty. The vertical line represents the weighted mean deglaciation age and the shaded area represents the associated $\pm 1 \sigma$ uncertainty. Asterisked $(*)$ samples are anomalous outliers that significantly pre-date deglaciation or differ significantly from two other ages obtained from the same site.

$81 \times 70 \mathrm{~mm}(300 \times 300 \mathrm{DPI})$ 

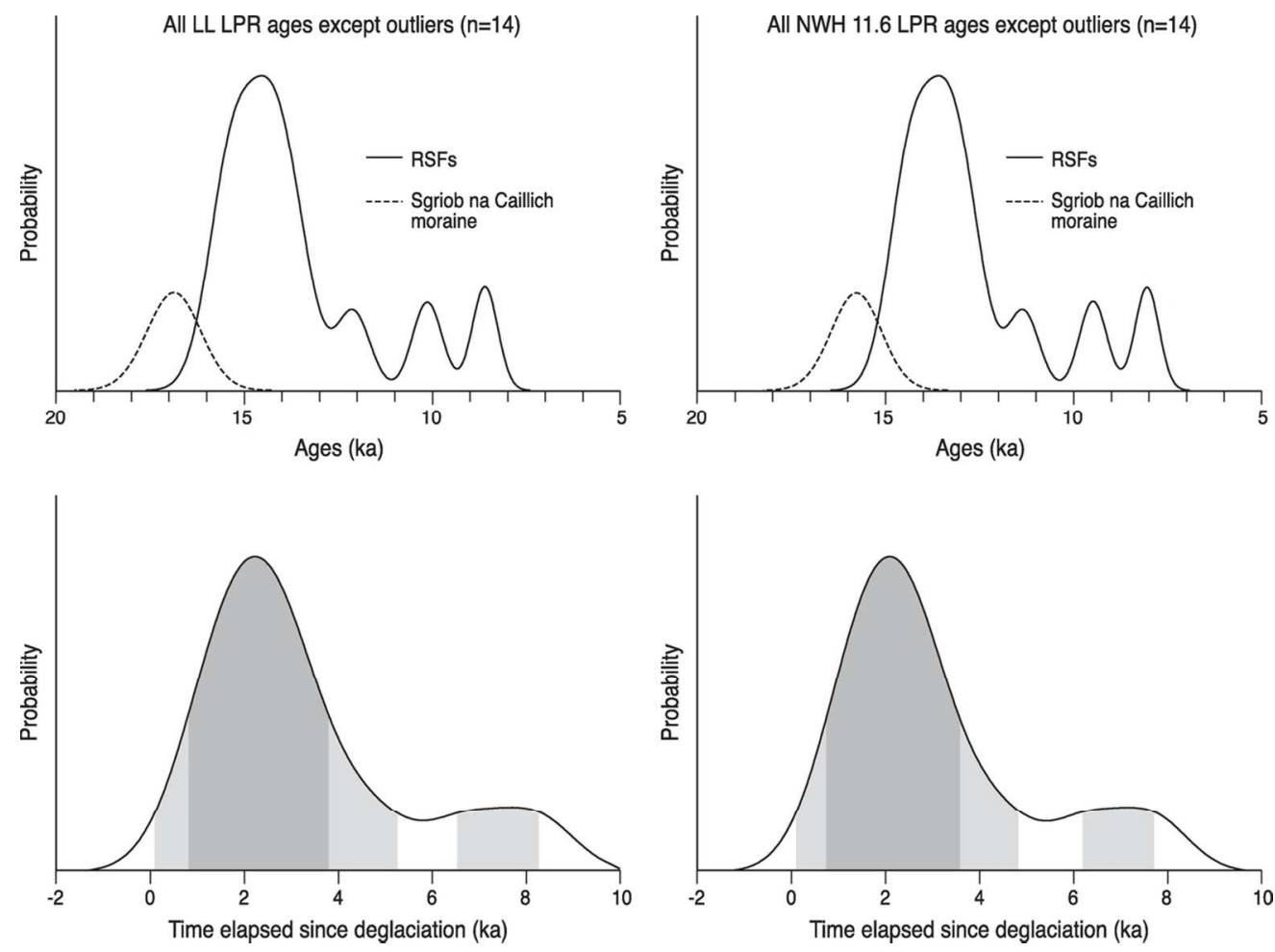

Figure 6 Top: Probability density distributions (PDDs) of the exposure ages obtained for the Scriob na Caillich moraine and the five RSFs on Jura, excluding outliers in both cases. Bottom: PDDs of the time elapsed since deglaciation based on PDDs shown on top. Left: ages calibrated using LL LPR. Right: ages calibrated using NWH11.6 LPR. The darker shaded zone represents $\pm 1 \sigma$ and the lighter shaded zone represents $\pm 2 \sigma$, demonstrating that all ages post-date the timing of deglaciation $(t=0)$ at $95 \%$ confidence. $112 \times 83 \mathrm{~mm}(300 \times 300 \mathrm{DPI})$ 


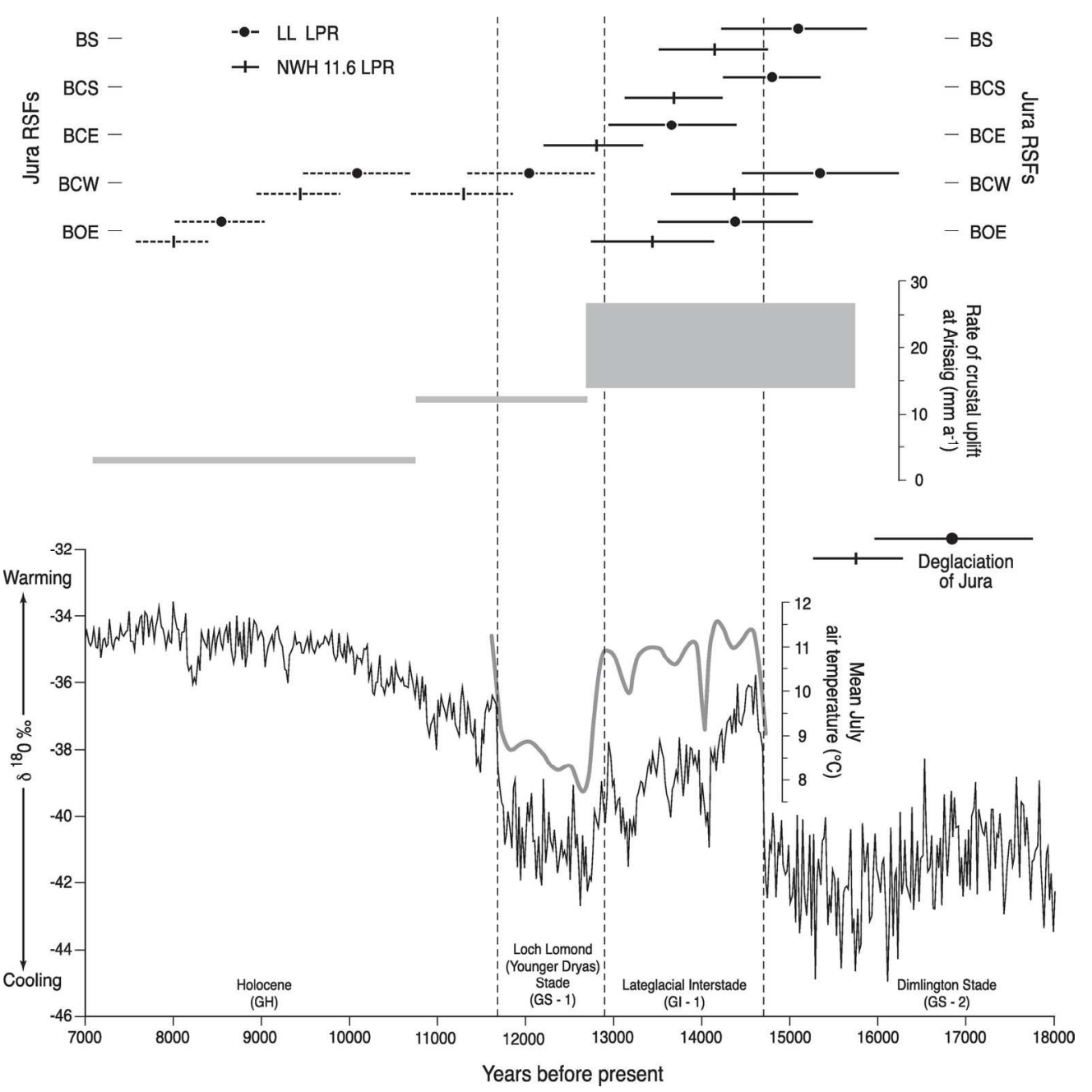

Figure 7. Uncertainty-weighted mean ages for three Jura RSF runout deposit (BS, BCS, BCE) and all postglacial ages for the remaining two (BCW, BOE) plotted against: (1) crustal uplift rates for Arisaig (from Firth and Stewart, 2000); (2) the timing of deglaciation of Jura (this study); (3) NGRIP ice core $\delta 180$ data for 7-18 ka (Rasmussen et al., 2006); (4) the ice core stages proposed by Lowe et al. (2008); and (5) mean July temperature data inferred from chironomid assemblages in SE Scotland (Brooks and Birks, 2000), matched to the NGRIP ice core data. Solid circles represent ages calculated using LL LPR, and vertical dashes represent ages calculated using NWH11.6 LPR. Solid horizontal lines represent $\pm 1 \sigma$ external uncertainties for the weighted mean ages (BS, BCS, BCE) and the most probable individual ages for $\mathrm{BCW}$ and BOE. Dashed horizontal lines represent $\pm 1 \sigma$ external uncertainties for the younger ages obtained for $\mathrm{BCW}$ and $\mathrm{BOE}$. $155 \times 155 \mathrm{~mm}(300 \times 300$ DPI $)$ 